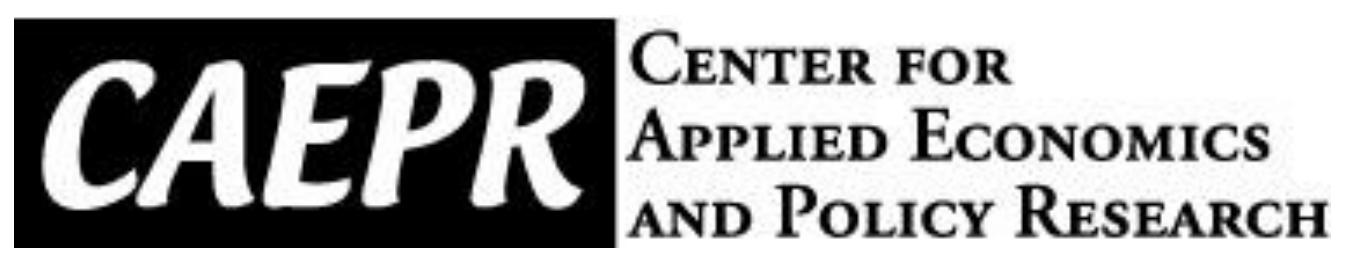

CAEPR Working Paper

\#2011-004

\title{
Salary Schedules, Teacher Sorting, and Teacher Quality
}

\author{
Gregory Gilpin \\ Montana State University
}

May 5, 2011

This paper can be downloaded without charge from the Social Science Research Network electronic library at: http://ssrn.com/abstract=1840524.

The Center for Applied Economics and Policy Research resides in the Department of Economics at Indiana University Bloomington. CAEPR can be found on the Internet at:

http://www.indiana.edu/ caepr. CAEPR can be reached via email at caepr@indiana.edu or via phone at 812-855-4050.

(C2011 by Gregory Gilpin. All rights reserved. Short sections of text, not to exceed two paragraphs, may be quoted without explicit permission provided that full credit, including $\odot$ notice, is given to the source. 


\title{
Salary Schedules, Teacher Sorting, and Teacher Quality
}

\author{
Gregory Gilpin
}

This study investigates how salary rigidities affect teacher quality across teaching subjects and high schools and whether high quality teachers can be compensated sufficiently to attract them into unfavorable schools. For identification, we rely on idiosyncratic variations in compensation across adjacent districts within the same state. The results indicate that, on average, math/science teachers' scholastic aptitudes are 8.5 percentiles lower and humanities teachers are 4.5 percentiles lower compared to other teachers. Furthermore, we find that schools with higher percentages of student eligible for free lunch hire teachers with, on average, 7 to 17 percentiles lower scholastic aptitudes with the math/science teachers being even lower. Increases in lifetime compensation is found to raise the scholastic aptitude of teachers hired across all schools, with diminishing returns in schools with more favorable working conditions. However, the lower $26 \%$ of the teacher aptitude distribution seems to not respond to compensation at all with only marginal gains up to the $60^{\text {th }}$ percentile. Furthermore, bonus/merit pay or additional school activity income do not seem to be significant in recruiting/retaining high aptitude teachers.

KEYWORDS: Salary Schedules, Incentive-based Pay, Math and Science Teachers, Wage Gradient, Teacher Sorting, Teacher Quality

JEL classification codes: I22, J31, H72

Department of Agricultural Economics and Economics, Montana State University, Linfield Hall, Bozeman, MT, 59717, Phone: (406) 994-5628. 


\section{Introduction}

An increased emphasis on teachers has been seen in the education reform debate following the passing of the No Child Left Behind Act of 2002 and the Race to the Top Fund, with particular concern over the quality of math and science instruction. Hiring qualified math and science teachers can be particularly difficult due to salary schedules equalizing pay across teaching subjects and teacher quality. ${ }^{1}$ This wage rigidity causes individuals to sort into teaching and non-teaching occupations as well as teachers to sort across school districts with higher quality teachers sorting into schools with more favorable work environments. ${ }^{2}$ What makes math and science teachers different from other teachers is that those who obtain a major in math or a science in college can potentially earn substantially higher wages in the non-education labor market, i.e., the wage elasticity of math/science teachers is potentially very different than that of other teachers.

The teacher sorting literature has shown that when compensation is rigid, teachers sort based on school/district characteristics. ${ }^{3}$ Teachers with more experience and degrees from more competitive colleges sort into counties with higher per capita income as well as by the percent of non-white students (see Ehrenberg and Brewer (1994) and Lankford, Loeb, and Wyckoff (2002)). These results have been confirmed by Jackson (2009) using post desegregation data who finds that schools that experienced a repatriation of black students experienced a significant decrease in teacher experience, level of teachers' degrees, and competitiveness of

\footnotetext{
${ }^{1}$ A salary schedule is a pay grade matrix that dictates teachers' salaries by years of experience and educational attainment. The schedule may also provide salary reductions due to probationary statuses or any additional pay to certain types of teachers, i.e., compensation to retain teacher in areas of shortage. The schedule may be self-imposed by schools or may be the result of bargaining between teachers' unions and school boards.

${ }^{2}$ In recent news, an Ohio mother was convicted of falsifying her residency records to enroll her child in a neighboring school district. Copley-Fairlawn School District indicated that she was cheating because her daughter received a quality education without paying taxes to fund it (see Canning and Tanglao (2011)).

${ }^{3}$ Podgursky, Monroe, and Watson (2004) using Missouri data shows that math and science teachers, higher scholastic aptitude teachers, and those who attended higher quality undergraduate institutions do not receive significantly different wage offers than their colleagues with lesser credentials.
} 
teachers' college. ${ }^{4}$ Bonesrønning, Falch, and Strøm (2005) also finds that when wages are rigidly structured, teachers sort themselves into schools by workload in Norway. Studying the labor supply of teachers, Engel and Jacob (2011) shows that the demographic characteristics of schools have significant effects on the number of applicants per vacancy, with the expected direction. Interestingly, even the size of district can have an effect on teacher sorting. Heutel (2009) using a tournament model demonstrates that higher quality teachers will accept equivalent pay to low quality teachers if they have higher probabilities of obtaining administrative positions. Research has also found that teachers sort across school types with teachers with better academic credentials sorting into private and charter schools rather than traditional public schools (see Podgursky (2008)).

To date, little empirical research has been conducted to determine how big financial incentives need to be to attract and retain teachers in hard-to-staff schools. Three notable papers have studied the effect of compensating differentials for higher quality teachers to remain in unfavorable schools. Levinson (1988) finds that teachers demand higher wages to teach less wealthy, lower-achieving students and that since wealthier schools demand and pay for better teachers, the expected wage benefit is reverse. Studying teacher transfers out of Milwaukee, Imazeki (2005) finds that it would take substantial increases in pay to retain teachers in this unfavorable area. Given that these teachers make the joint decision of where to live and work, this effect may overstate the amount an unfavorable urban school must pay to obtain higher quality teachers. Clotfelter et al. (2008) using data from North Carolina finds that bonus payments of $\$ 1,800$ to certified math, science, and special education teachers working in highpoverty or low test score schools reduced teacher turnover by $17 \%$ with experienced teachers being the most responsive. It is not certain that it is the recognition in the workplace or the

\footnotetext{
${ }^{4}$ Similar results are found in Clotfelter, Ladd, and Vigdor (2007)
} 
compensation that reduced attrition. In any event, this result is somewhat unique as a small change in lifetime compensation produces a substantial reduction in attrition.

Teacher sorting would be of little concern if teacher quality had no effect on student achievement. In recent years there has been an abundance of papers that demonstrate that teachers matter. Ferguson $(1991,1996)$ finds significant positive effects of teacher test scores on student test scores in Texas and Alabama schools respectively. Similarly, Strauss and Sawyer (1986) find that a $1 \%$ increase in the standardized test scores of teachers increases the pass rates of North Carolina high school students by $5 \%$ on math and reading proficiency tests. Ehrenberg and Brewer (1994), using national data, find that the quality of a teacher's undergraduate institution is highly related with student test outcomes and that a one category increase in the selectivity of a teacher's institution is associated with a $1-2 \%$ increase in student test scores. ${ }^{5}$ Aaronson, Barrow, and Sander $(2007)$ examine $9^{\text {th }}$-grade math teachers in Chicago Public Schools and find an effect between observable teacher characteristics and student outcomes, with one of the strongest effects coming from a teacher's undergraduate major. Math and science majors were found to have a positive effect on math scores while education majors had a negative effect. Monk (1994) examines the impact of subject knowledge, such as a major or minor in the subject taught, and finds significant gains in student learning for U.S. high school students. Monk further finds these subject knowledge gains to be particularly strong in math and science subjects. Clotfelter, Ladd, and Vigdor (2007) make use of detailed data on $3^{\text {rd }}-5^{\text {th }}$ grade students in North Carolina public schools and find that the effect of improved teacher credentials is especially strong in math achievement. It appears that the effect is non-linear with bigger effects found at either end of the teacher quality distribution. Goldhaber and Anthony (2007) also make use of North Carolina data to examine the effects of the National Board Certification

\footnotetext{
${ }^{5}$ Further examples include Hanushek (2010), Rockoff (2004), Loeb and Page (2000), Summers and Wolfe (1977), and Winkler (1975) who find similar positive effects on student achievement.
} 
process and find mixed evidence that improved observable teacher credentials such as degree type and level have positive impact on student achievement. For a general survey of the literature linking teacher academic ability and student achievement, Greenwald, Hedges, and Laine (1996) and Hanushek $(1981,1986)$ provide an excellent summary of previous findings. These surveys generally conclude that of all measurable school and teacher characteristics, academic ability of teachers has the largest effect on student outcomes. As Hanushek (1981) states, "[t]he only relatively consistent finding is that 'smarter' teachers seem to do better in terms of student achievement."

This study examines whether increasing teacher compensation in unfavorable schools can overcome higher quality teachers' reluctance to work in them. We focus on math/science and humanities teachers as quality is imperative to core education production compared to nonmath/science/humanities teachers. The questions this paper attempts to answer are 1) how do salary schedules affect teacher quality across subjects?, 2) how do salary schedules affect teacher quality across schools?, and 3) how much and what types of compensation do math/science and humanities teachers require to sort into less favorable schools? To answer these questions, we estimate the effect of various compensation and work environment characteristics on general scholastic aptitude and subject-specific scholastic scores of teachers hired. ${ }^{6}$ For identification, we rely on idiosyncratic variations in compensation across adjacent districts within the same state. This permits us to identify how scholastic aptitudes teachers hired are affected by school and compensation characteristics. We then study how compensation affects the aptitude of teachers hired in unfavorable schools. This is done by analyzing the responsiveness to teachers

\footnotetext{
${ }^{6} \mathrm{We}$ measure general scholastic aptitude as the teachers' percentiles in the distribution of scholastic aptitude of all college students and subject-specific scholastic aptitude as teachers' percentiles in the distribution of scholastic aptitude of college students majoring in her teaching subject. For example, a math teacher's subjectspecific scholastic aptitude is measured as her percentile in the math/sciences college majors' scholastic aptitude distribution.
} 
in the fourth quartile in the percent eligible for free lunch, a key indicator used by teachers to sort across schools, and then determine how much compensation raises scholastic aptitude of teachers hired in these schools.

The results indicate that math/science and humanities teachers hired have, on average, 2 - 2.5 percentiles higher general scholastic aptitudes. On the other hand, compared to their respective college peers, math/science teachers have, on average, 8.2 percentiles lower scholastic aptitude compared to math/science majors and humanities teachers have, on average, 4.5 percentiles lower scholastic aptitude compared to humanities majors. These correspond to a half standard deviation and a quarter standard deviation decline in scholastic aptitude, respectively. This decline can be attributed to the use of salary schedules equalizing pay across teaching subjects. Consistent with the literature, aptitude and teacher experience are inversely related. The estimation results also suggest that controlling for student characteristics, a 1.25\% increase in lifetime compensation can mitigate the decline in subject-specific scholastic aptitude of math/science teachers and a little less than a $1 \%$ increase for humanities teachers. However, the quantile regression estimates indicate that only the upper $75 \%$ of the aptitude distribution for math/science teachers respond to increases in compensation. This implies that across the board increases in compensation will, in the long-run, increase teacher quality but at a substantial cost of paying $25 \%$ of teachers more without any change in quality hired. The results clearly show that teachers sort primarily on the percent of students in their school eligible for free lunch and little evidence for the percent of non-white students. For these unfavorable schools, we find larger attrition rates of higher scholastic aptitude teachers than favorable schools for math/science teachers and humanities teachers. Furthermore, the effect of compensation on the scholastic aptitude of teachers hired is almost twice as large for math/science and humanities teachers. However, teachers below the bottom $50^{\text {th }}$ percentile in aptitude seem to not respond at 
all to pay increases.

The results of this paper extend the literature in multiple dimensions. First, this paper documents how salary schedules affect the scholastic aptitude of math and science teachers. Given that math and science teachers generally have higher scholastic aptitudes, this paper shows that it is not general scholastic aptitude that declines due to salary rigidities but rather subject-specific scholastic aptitude, i.e., the scholastic aptitude of teachers relative to their respective subject matter college peers. Second, this paper quantifies the relative importance of compensation versus school characteristics for sorting math/science teachers as well as for humanities teachers across the entire scholastic aptitude distribution, identifying non-linear effects of compensation and school characteristics. Lastly, the paper provides clear policy implications on whether compensating differentials can entice higher aptitude teachers to sort into less favorable schools.

The paper is organized as follows. Section 2 develops a theoretical model that frames the effect of the wage rigidity on the equilibrium quality of teachers hired at a particular school. Section 3 provides information on the data construction and summary statistics, while section 4 provides the empirical strategy. Section 5 contains the main empirical results and section 6 concludes.

\section{The Theoretical Framework}

In order to provide an empirical framework in which to examine the impact of contract rigidities, we provide a theoretical model for the teacher staffing decision. The basic structure utilized here is similar to that of Gilpin and Kaganovich (2009). The objective of a school is to produce the highest per student education quality possible given the available budget. ${ }^{7}$ For simplicity,

\footnotetext{
${ }^{7}$ While the unit of analysis is the school level, little is lost by assuming a district-level analysis.
} 
we assume that schools combine teacher inputs to educate students in two broad categories: math/science and humanities subjects and abstract from differences in the size of the student bodies across schools. The budget constraint of a school is

$$
B=\int_{\Omega_{s}} w_{s}\left(\omega_{s}\right) n_{s}\left(\omega_{s}\right)+\int_{\Omega_{h}} w_{h}\left(\omega_{h}\right) n_{h}\left(\omega_{h}\right)+T
$$

where $w_{k}\left(\omega_{k}\right)$ are the market wage rates exogenously given to the school for aptitude $\omega_{k}$ while $n_{k}\left(\omega_{k}\right)$ is the quantity of individuals hired with aptitude $\omega_{k}$ for $k=s, h$. The index, $k$, simply indicates the subject being taught where $s$ is for the math/science subjects and $h$ is for humanities subjects. This is important to keep in mind as we assume that teachers are hired by teaching subject and not necessarily by degree type. The ability distributions of individuals, $\Omega_{s}$ and $\Omega_{h}$, are taken as given along with the total budget, $B$. The third term on the right-hand side, $T$, is the cost of non-math/science/humanities teachers and non-teaching inputs in education production. The objective function of high schools is to maximize per student education quality according to:

$$
E=f\left(D, A_{s}, Q_{s}, A_{h}, Q_{h}\right)
$$

where $D$ is all other educational inputs not related to math/science/humanities teachers, $A_{k}=$ $\int_{\Omega_{k}} g\left(a\left(w_{k}\right) n_{k}\left(\omega_{k}\right)\right)$, is defined as the aggregate quality and $Q_{k}=\int_{\Omega_{k}} l\left(n_{k}\left(\omega_{k}\right)\right)$, is the aggregate quantity of teachers with aggregation functions $g(\cdot)$ and $l(\cdot)$. Education quality is increasing but diminishing in all inputs. Given (1) and (2), high school administrators' maximization problem can be constructed. The administrators choose the quantity of math/science and humanities teachers at each level of ability, $n_{s}\left(\omega_{s}\right) \forall \omega_{s} \in \Omega_{s}$ and $n_{h}\left(\omega_{h}\right) \forall \omega_{h} \in \Omega_{h}$ and the amount of non- 
teaching input, $D$, to maximize

$$
\max E \text { s.t. } B=\int_{\Omega_{s}} w_{s}\left(\omega_{s}\right) n_{s}\left(\omega_{s}\right)+\int_{\Omega_{h}} w_{h}\left(\omega_{h}\right) n_{h}\left(\omega_{h}\right)+T
$$

Abstracting from the decision to allocate funds between the non-teaching inputs and teaching inputs, the school maximizes education quality by adjusting the resources expended on teachers in both subject areas. The teacher inputs can be increased either by hiring more teachers in a given subject or by hiring higher quality teachers. Thus, for a given budget, schools choose the quantity and quality of teachers in each subject area.

In addition to the school's hiring decisions, we also model individuals' employment choice. Individuals with ability $\left\{\omega_{s}, \omega_{h}\right\}$ face a decision whether to teach or work outside of teaching and, if they choose to teach, which subject and school. Thus, potential teachers face the following problem

$$
\max \left\{U_{j}\left(w_{j}, l_{j}, v_{j}\right) \forall j \in J, U_{0}\right\}
$$

where $U_{j}$ is the indirect utility of a teacher offered a job at school $j$ and $J$ is the set of all offers. The indirect utility received from each teaching job offer is a function of the wage $w_{j}$, workload $l_{j}$, and environment $v_{j}$ they would face at that school. $U_{0}$ is the indirect utility they would receive from working outside of teaching.

Given the framework outlined above, the market for teachers is characterized by a complex set of decisions by school administrators and individuals. However, the model does allow some predictions about the effect of imposing a uniform salary structure across subjects as well as across schools. To obtain these predictions, we make a few simplifying assumptions about the structure of the education quality function. The first is that schools maximize an education quality objective that requires both math/science and humanities teachers, e.g., the graduation 
rate or college attendance rate. Since both are required for education production, both are restricted to being essential and somewhat non-substitutable, i.e., the return on math/science and humanities teachers (quantity and quality) are both bounded to be greater than 0 . The second assumption is that the quantity-quality production trade-off for both subjects are equal. This variable is parameterized as $\rho$. The last assumption is that school administrators buy bundles of similar quality teacher for a given subject, i.e., they choose one type of quality per subject when buying a set of teachers. Given these assumptions, the education quality maximizing solution is

$$
\frac{Q_{s}^{*}}{Q_{h}^{*}}=\left(\frac{\varepsilon_{A_{s}, w_{s}}}{\varepsilon_{A_{h}, w_{h}}}\right)^{1 / \rho} \frac{A_{s}^{*}}{A_{h}^{*}}
$$

where $\varepsilon_{A_{j}, w_{j}}$ is the elasticity of wages with respect to aptitude in subject $j$ and $\rho$ is the elasticity of substitution between quantity and quality of teachers. Thus, depending on the relative size of the wage elasticities of quality across subjects, the quality purchased between subjects may be equal to or greater than the other. ${ }^{8}$ Assuming that $\varepsilon_{A_{s}, w_{s}}>\varepsilon_{A_{h}, w_{h}}$, eq. (5) is the optimal quantity and quality of teachers. When $\rho$ is 1 , quantity and quality of teachers are perfectly substitutable and the optimal quantity and quality of teachers is dictated by the differences in the elasticity of wages with respect to aptitude across subjects. When $\rho$ is $-\infty$, the quantity and quality of teachers are complementary and require fixed proportions in both the quantity and quality of teachers to improve education quality. In what follows, we restrict $\rho$ to be positive and strictly less than 1.

We can now analyze the optimal quality of teachers under rigid wages across teaching subjects. First, assuming that the school work condition policy (dictated by a collective

\footnotetext{
${ }^{8}$ While earnings tend to be larger for higher aptitude math/science individuals than humanities individuals in the non-education workforce, this may not be true for the individuals who have entered the education sector. Math/science teachers may have fewer wage opportunities outside of teaching than humanities teachers given the type of individual who decides to teach in math/science versus the type of individual who decides to teach in the humanities.
} 
bargaining contract or a self-impose mandate) equalizes class sizes across subjects, i.e., the lefthand side of (5) is 1 , then the optimal quality of math/science teachers is less than the optimal quality of non-math/science teachers. ${ }^{9}$ Second, assuming that the school has a salary schedule (dictated by a collective bargaining contract or self-imposed policy), then the optimal solution is to increase the quantity of math/science teachers more than in the case with no wage rigidity and hire math/science teachers of relatively lower quality. Third, assuming that the school has a salary schedule and a class size policy, then the optimal solution for the school is to hire math/science teachers of relatively lower quality than in the case with no contract rigidities.

We can now place this single school's problem within an array of schools that compete in the teacher labor market. There are two scenarios that are worthwhile to discuss. If schools are given a fixed budget identical to all other schools by state mandate, then teachers will sort by their preferences across schools with more preferred schools hiring the highest quality teachers. When schools have budgets dictated by local taxes, teacher compensation is adjusted across communities until teacher quality reflects the demand by families in their respective communities. Under this scenario, higher quality teachers will be observed in communities that demand higher quality teachers. In reality, most schools are in communities that lie somewhere between these two extremes with some of the funding coming from local revenues and the remaining coming from state revenues. Given that teacher compensation is funded from state or even federal funds, an analysis 'on the margin' of teacher quality can be conducted by comparing the hiring outcomes of various schools with similar working conditions who differ in compensation.

\footnotetext{
${ }^{9}$ Given that class size is perfectly observable, the enforcement of 'Equal Pay for Equal Work' typically constrains workloads to be equal across subjects. Furthermore, initial regressions using class size and other workload characteristics indicate there is no statistically significant difference between math/science and humanities teachers' workloads.
} 


\section{Data}

The primary data for this study comes from the 1999-2000, 2003-04, and 2007-08 restrictedaccess version of the Schools and Staffing Survey (SASS) conducted by the National Center for Education Statistics. This survey incorporates questionnaires from roughly 50,000 teachers in 10,000 public schools every four years. The SASS data contain exact wage and benefit data along with several school/district characteristics.

Teacher quality is measured as a teacher's general schlastic aptitude and subject-specific scholastic aptitude. We measure general scholastic aptitude as the teachers' percentiles in the distribution of scholastic aptitude of all college students and subject-specific scholastic aptitude as teachers' percentiles in the distribution of scholastic aptitude of college students majoring in her teaching subject. For example, a math teacher's subject-specific scholastic aptitude is measured as her percentile in the math/sciences college majors' scholastic aptitude distribution. While we recognize that there are other components of a teacher's quality that contribute to the performance of students, previous findings in the literature such as Greenwald, Hedges, and Laine (1996), Hanushek (1981, 1986) and Hanushek et al. (2005) suggest that the largest effect on high school student achievement among measureable teacher quality characteristics is a teacher's scholastic ability.

We construct subject-specific scholastic aptitudes of teachers to assure that we are measuring within-subject scholastic aptitude and not general aptitude. Using subject-specific scholastic scores assures that the true effects of subject-specific aptitude are identified for each teaching subject and not the confounded effect of higher general scholastic aptitude teachers switching teaching subjects. To construct subject-specific scholastic aptitudes, we first standardize all undergraduate college students' ACT and SAT scores from six rounds (1989-90, 1992-93, 199596, 1999-00, 2003-04, 2007-08) of restricted-access versions of the National Post-Secondary 
Aid Survey (NPSAS). ${ }^{10}$ We then construct subject-specific scholastic aptitude distributions, one for math/science majors, one for humanities majors, and another for all other majors using the standardized scores for the college students. ${ }^{11}$ The subject-specific scholastic aptitudes of teachers are then constructed by taking the teachers' scholastic aptitude scores and determining their corresponding percentiles in their main teaching subject's distribution (math/sciences, humanities, or all other).

Since the SASS only provides the majors as well as the undergraduate institutions of the teachers and not their actual ACT or SAT scores, we impute their scores based on the average scholastic aptitude of the college students who also majored with them at their institution. As a measurement of scholastic ability, this imputed value provides better precision than using either the college selectivity or college ranking such as those found previously in the literature. By construction, our scholastic measurement has the advantage of not mixing scholastic scores across majors as there may be significant differences in the aptitude of students across majors within the same university. ${ }^{12}$ This assumption is somewhat validated by the fact that the sample variance of scholastic aptitudes is higher across majors within a university than across all universities within a major. ${ }^{13}$

Table 1 provides summary statistics on the scholastic aptitudes of college students and teachers as measured by their percentile in the various scholastic aptitude distributions. All college students' aptitude scores are standardized as indicated in the table by the average aptitude of college students being the $50^{\text {th }}$ percentile. College students majoring in math/science

\footnotetext{
${ }^{10}$ Raw scholastic scores and references to converting SAT to ACT scores is found in the appendix on Table A.3.

${ }^{11} \mathrm{~A}$ list of majors classified by subject can be found in the appendix on Table A.1.

${ }^{12}$ The disadvantage of this approach is that scores are detrended across years to obtain a sufficient sample of students within each university-major. However, the majority of the literature also does not permit institutional quality to vary across years.

${ }^{13}$ For double majors and second degree teachers, we take the arithmetic average of their scholastic aptitudes across their majors.
} 
disciplines are, on average, 14 percentiles higher in aptitude than all college students compared to students majoring in the humanities disciplines who are, on average, 3.2 percentiles higher aptitude than all college students. Interestingly, education majors are 11.4 percentiles lower aptitude than the average college student or an entire standard deviation away from math/science majors. The spread between math/science and humanities teachers is much smaller than the spread between math/science and humanities college student and the distribution of scholastic aptitudes for all teaching subjects is tighter than the distributions for college graduates. While math/science teachers are relatively similar to other teachers in general aptitude, this is not the case with respect to subject-specific scholastic aptitude. Placing math/science teachers' aptitudes into the math/science subject-specific aptitude distributions, and similarly for all other teachers, indicates that math/science teachers are, on average, 8 percentiles lower aptitude than other math/science majors and that humanities teachers are, on average, 2.6 percentiles lower aptitude than humanities majors. This is mostly driven by the types of colleges teachers select. Special education teachers and all other teachers have similar aptitudes to typical college students.

The correlation between general aptitude and subject-specific aptitude for teachers is provided at the bottom of Table 2 by major. Humanities majors have the highest correlated measures of aptitude, e.g., a high general aptitude equates to a high subject-specific aptitude, while education majors have the lowest correlation between aptitudes. The low correlation of education majors indicates that relative to humanities or math/science majors, education majors are of lower aptitude. Given that teachers can teach classes outside of their subjectarea knowledge, e.g., humanities majors can teach math, and the correlations of aptitudes are not the same across majors, this provides reason for using the subject-specific aptitude measure over the general measure.

We also create three measures of compensation from the SASS data. The first is lifetime 
teacher income defined as the current value of the expected future flow of income over a forty year teaching career in her current school. We construct this for those that have a bachelor's degree (labeled $B A$ ) and for those that have a master's degree or beyond (labeled $M A$ ) using

$$
P I_{e d}=\operatorname{startpay}_{e d} * 40+\left(\operatorname{step}_{e d} * 40^{2}\right) / 2
$$

where $e d=\{B A, M A\}$ and startpay $_{e d}$ is the starting pay of teachers for education attainment $e d$ with corresponding annual salary increase steps of $s t e p_{e d}$ in the teachers' district. ${ }^{14}$ The advantage of this particular measure is that it is exogenous to teachers' experience. Thus, only shifts in the salary schedule are identified and not simply movements along the schedule (see Hanushek, Kain, and Rivkin (1999) for similar analysis). The second measure of compensation is the reported annual merit/bonus pay teachers receive. This pay is not for additional responsibilities but rather added on top of the teachers' regular pay. The third measure of compensation is annual additional activities income. This includes summer school compensation as well as compensation for all other extracurricular activities. This may be given to teachers in an effort to raise their salaries. All three compensation measures are significantly right skewed. After logging the measures, all have shape parameters of being normally distributed.

Table 3 breaks down summary statistics on scholastic aptitude, whether the teacher has a degree in her teaching subject, and compensation for math/science teachers and humanities teachers, respectively. This table demonstrates that as the number of student eligible for free lunch increases, the average scholastic aptitude of teachers hired declines, the probability of the teacher having a degree in her teaching subject declines, and compensation decreases. The descriptive statistics do not attribute the decline in teacher quality to lower compensation or

\footnotetext{
${ }^{14}$ Given that starting pay and the step are not always positively related, it provides a precise calculation that is comparable across all districts.
} 
student characteristics.

Summary statistics for the teacher and school/district level variables are found in Table 4 for math/science and humanities teachers. The summary statistics indicate that $45 \%$ of the total sample are math/science teachers while $55 \%$ are humanities teachers. Subsampling the data, $48.9 \%$ of math/science teachers are male compared to $40 \%$ of humanities teachers. ${ }^{15}$ It should be noted that only community level characteristics measuring population density, whether the school is in the rural or in a metropolitan area, are included. This may appear to be a severe omission since teachers may use other community characteristics when they are deciding to accept employment in certain schools. Using factor analysis, we find that the community-level characteristics (community income and percent of adult population with at least a bachelor's degree) have high communalities (71.1\% and $61.7 \%$ respectively) with the school characteristics (percent of student body eligible for free lunch, percent of student body being a minority, whether the school is in a metro area, and whether the school is in a rural area) variables. Furthermore, both had eigenvalues less than one which lends support to excluding them over the school characteristic variables.

\section{Empirical Specification}

The empirical strategy is based on the theoretical model. The theoretical model demonstrates that schools choose the quality of teachers according to the limits of their budget constraint and the wages that teachers of various scholastic aptitudes are willing to accept for each teaching subject. For their part, teachers accept an offer based on a combination of wages and non-pecuniary school characteristics as well as other idiosyncratic reasons. Thus, the observed teacher aptitude

\footnotetext{
${ }^{15}$ The categorization of high school classes into math/sciences, humanities, and other classes is found in the appendix in Table A2.
} 
of a particular teacher hired is the outcome of the joint decisions of school administrators and the individual teachers. We estimate a reduce form equation with teachers' scholastic aptitude as the dependent variable and the compensation measures, teacher and school characteristics, as well as other controls as independent variables according to ${ }^{16}$

$$
A_{i, j}=\alpha_{0}+\operatorname{Comp}_{i}^{\prime} \alpha_{1}+X_{i}^{\prime} \alpha_{2}+X_{j}^{\prime} \alpha_{3}+\delta_{s}+\delta_{m}+\varepsilon_{i, j}
$$

where $A_{i, j}$ is the observed scholastic aptitude of teacher $i$ hired in school $j, \operatorname{Comp}_{i}$ is a vector of teacher compensation measures, $X_{i}$ represents vectors of teacher characteristics, $X_{j}$ represents vectors of school characteristics, $\delta_{s}$ and $\delta_{m}$ are state fixed effects and urbanicity dummies, and $\varepsilon_{i, j}$ is the error term. Given that teachers are not paid compensating differentials for unfavorable school characteristics, compensation and school environment characteristics can be included together without any endogeneity issues (see Gilpin (forthcoming) for further details). ${ }^{17}$ Furthermore, given our construction of teacher compensation, teacher experience can also be included on the right-hand-side as it is uncorrelated with lifetime teacher income. Lastly, we also include state fixed effects to control for unobservables that may biased the work environment or compensation coefficients. We do this since districts mostly hire individuals from within state and scholastic aptitude may be highly correlated with in-state college selectivity. The results of this analysis will provide the effects of various work environment characteristics on teacher aptitude controlling for compensation measures. Subsampling the data to only teachers in the most unfavorable schools, we control for working conditions and then can exploit

\footnotetext{
${ }^{16}$ It is through sorting (and in particular recruitment and retention) that teacher quality changes and not simply through increases in compensation to existing teachers. This implies that the observed teacher quality is a function of schools' and teachers' decision making and that this can be influenced through changes in school policies and teachers' decisions.

${ }^{17}$ Paying all teachers the same amount in all districts in a particular state is different from providing additional compensation to teachers working in unfavorable schools.
} 
variation in compensation to understand whether and how much higher quality teachers must be compensated to work in these schools. We define the unfavorable schools as those having an effect of teachers' decision to sort away from them.

We further investigate the effects through quantile regression. To do this, the analysis groups teachers based on their subject-specific scholastic aptitudes and then determines whether groups of different aptitude teachers respond differently to compensation and work environment characteristics. We do this since the effect of compensation and school characteristics may be non-linear, e.g., low aptitude teachers may respond differently to working conditions than high aptitude teachers. Thus, equation (7) becomes

$$
A_{i, j}(\tau)=\operatorname{Comp}_{i}^{\prime} \alpha_{0}(\tau)+X_{i}^{\prime} \alpha_{1}(\tau)+X_{j}^{\prime} \alpha_{2}(\tau)+\delta_{s}(\tau)+\delta_{m}(\tau)+\varepsilon_{i, j}(\tau)
$$

where the variables are as described in eq. (7) with the addition of $\tau$ representing a given percentile of scholastic aptitude. ${ }^{18}$

\section{Empirical Results}

Prior to estimating the model, we investigate the magnitude of the intraclass correlation of having teacher observations within the same school, if intraclass correlation is high, i.e., many teachers in a given school are quite similar, then the effect of lifetime teacher compensation is not identified. To investigate the intraclass correlation, we first investigate how many teachers are within each school and then test the intraclass correlation statistics similar to an analysis of variance for the dependent variables. $50 \%$ of all schools has two or less teachers in the sample while almost $80 \%$ of the sample has four or less teachers. Given that we investigate math/science

\footnotetext{
${ }^{18} \mathrm{Ma}$ and Koenker (2006) provide an in-depth analysis and comparison of various methods to estimating quantile regressions.
} 
teachers and humanities teachers separately, this implies that roughly $80 \%$ of the sample will have two or less teachers for each school-subject level. Further evidence of small intraclass correlation is provided through the statistically significant intraclass correlation statistic of .12 for teachers' aptitude. Having low intraclass correlation for quality teachers demonstrates that clustering is minimal.

To investigate how clustering impacts the significance of the coefficient estimates, we run each equation separately with homoscedastic, heteroscedastic robust, and cluster robust standard errors at the school level. The statistical significance of the standard errors remains the same across these three estimations even though the cluster robust standard errors are higher than the standard and robust standard errors as expected. Another robustness check is to remove the state fixed effects to see how large an issue unobservable effects are. As reported in Tables 5 and 6, unobservables effects are quite minimal for math/science and humanities teachers, our primary groups of interest. While not reported, the coefficient estimates for non-math/science/humanities teachers without state fixed effects shows large differences in magnitude and significance.

\subsection{Estimation Results on General Scholastic Aptitude}

The coefficient estimates using the general measure of scholastic aptitude are presented in Table 5 with cluster-robust standard errors. The results of these regressions indicate that both math/science and humanities teachers have significantly higher general scholastic aptitudes of approximately $2-2.5$ percentiles while special education teachers have 1.7 percentiles lower aptitude. Teachers hired with advanced degrees have about $1.5-2$ percentiles higher aptitude and the aptitude of teachers is inversely related to teacher experience. Higher aptitude math/science/humanities teachers tend to exit teaching at almost twice the rate as high quality non-math/science/humanities teachers. In terms of teacher sorting, the results indicate that the 
percent of students eligible for free lunch has a significant effect of the scholastic aptitude of teachers hired, but not the percent of minority students regardless if state fixed effects are present or not. The magnitude is statistically similar between math/science and humanities teachers with a .5 percentile decline per 10 percent increase in students eligible for free lunch. Relative to other influences, this effect could be quite considerable going from the bottom quartile to the top quartile in percent of students eligible. Other school characteristics that had an effect are whether a union was present, lowering aptitude by approximately 1 percentile while the size of the district, as measured as the number of schools within a district, increases the aptitude of teachers hired. There are a variety of reasons that can explain this. Some examples include larger districts may increase the probability of being promoted to an administrative position for higher aptitude individuals compared to smaller districts or that there are clearer benchmarks for teachers in larger districts. Lastly, compensation seems to matter for teacher sorting with higher paying schools able to hire higher quality teachers. For every $1 \%$ increase in lifetime teacher compensation, math/science teachers and humanities teachers' aptitudes increase by approximately 7 to 7.5 percentiles while a $1 \%$ increase in bonus/merit pay increases teacher quality by .2 percentiles. As discussed above, estimates without state fixed effect varied little from those with state fixed effects included. Furthermore, including state fixed effects increases the effect of compensation on the aptitude of teachers hired. Thus, not including state fixed effects downward biases the effect of compensation.

\subsection{Estimation Results on Subject-specific Scholastic Aptitude}

Table 6 presents the results of the subject-specific scholastic aptitude estimated using fixed effects, urbanicity dummies, and cluster robust standard errors at the school level. We first estimate the effects jointly for all teachers for a baseline, and then estimate the 
same regression for math/science/humanities teachers, math/science teachers, and humanities teachers, respectively. This, in essence, unconstrains the control variables in each successive regression. After running each subsequent regression, we perform F-tests to see if the noncompensation coefficients across regressions are equal and these tests are rejected for all noncompensation variables. We also test if the compensation coefficients are equal as well. Tests on the coefficient of permanent income and bonus pay reject that all teachers and math/science teachers respond the same as well math/science teachers and humanities teachers. Testing that the coefficients on the compensation measures for math/science and humanities teachers fails to reject that they are identical. Thus, using average effects, math/science teachers respond similarly to compensation but not for working conditions.

The results indicate that the differences in scholastic aptitudes between non- math/science/humanities teachers and math/science teacher and humanities teachers, respectively, remain after controlling for compensation and school characteristics and other controls. This implies that the 8.5 percentile difference in scholastic scores of math/science teachers and the 4.5 difference for humanities teachers are most likely due to salary schedules equalizing pay across all teaching subjects. In terms of school sorting, the results indicate that the percent of the student body eligible for free lunch and the number of schools in the district determine how teachers sort. Furthermore, it seems that non-math/science/humanities teachers sort away from schools with relatively more minority students. ${ }^{19}$ The effect of free lunch is, on average, twice as large as the effect of having a large number of minority students. The estimation also indicates that the school being located in a metro area increases the scholastic aptitude of teachers hired. This is of little surprise as higher aptitude individuals are generally attracted to metropolitan areas for

\footnotetext{
${ }^{19}$ Robustness checks using the number of school squared and experience square in the same regression were both insignificant.
} 
culturally enriching activities and teachers may not need to work in the communities where their employment is located (see Ballou (1996) for similar results). The presence of a union has no effect on teacher sorting for all teachers.

The compensation variables reveal that all three measures of compensation have an effect on the subject-specific scholastic aptitude of teachers hired. The effect of lifetime teacher income has consistently significant effects on math/science and humanities teachers with the scholastic

aptitude of humanities teachers being effect greater than math/science teachers. Controlling for school characteristics, a $1 \%$ increase in compensation raising aptitude by 5 percentiles for math/science teachers and approximately 8 percentiles for humanities teachers. This implies that the wage elasticity of teacher quality is quite different across teaching subjects with humanities teachers being more elastic than math/science teachers. Schools that provide merit/bonus pay can attract higher subject-specific scholastic aptitude teachers as well. As will be shown in the results of the quantile regressions, merit/bonus pay is not effective as these results indicate. Lastly, additional school compensation seems to have a negative effect on aptitude of math/science teachers hired. This may indicate that school administrators are willing to hire an individual of lesser subject aptitude if they will lead extracurricular activities.

The statistically negative coefficient on teacher experience indicates that the attrition rate of higher subject-specific scholastic aptitude teachers is larger than their less able peers. The attrition rate of higher subject-specific scholastic aptitude teachers is larger for math/science than humanities teachers. These results on teacher attrition are complementary to the existing literature on teacher attrition.

\subsection{Quantile Estimation Results on Subject-specific Scholastic Aptitude}

Using a quantile regression framework, we are able to understand the effect of various covariates 
for teachers sorted by scholastic aptitude. We provide the coefficient estimates from these regressions for the $25^{t h}, 50^{\text {th }}$, and $75^{\text {th }}$ percentiles in Table 7 and graph the coefficients for quantile regressions every .025 percentiles for select variables on Figure 1 by teaching subject. These results indicate that compensating differentials for higher teacher quality may do little to aid in increasing subject-specific scholastic aptitude of lower aptitude teachers hired. For math/science teachers, increasing lifetime income is not statistically significant until the $28^{\text {th }}$ percentile and a $1 \%$ increase in lifetime income raises scholastic aptitudes of teachers by around 5 - 6 percentiles across the remaining distribution (See Figure 1 for more details). On the other hand, humanities teachers are more responsive to increases in compensation with increases in lifetime income of the lowest scholastic aptitude teachers by 5 percentiles until the $50^{\text {th }}$ percentile in which it increases to approximately 8 - 9 percentiles. A F-test for each percentile rejects that the effect of lifetime compensation are equal between math/science and humanities. This is a key finding which highlights the difficulty of attempting to raise teacher quality by increasing compensation, that the majority of the math/science distribution is unresponsive or mildly responds. This finding should not be taken that the scholastic aptitude of teachers cannot be raised, but rather it will increase if compensation is increased substantially.

Observing the effect of teaching experience over the scholastic aptitude distribution indicates that the higher scholastic aptitude math/science teachers are more likely to leave. The exact opposite result is found for humanities teachers, i.e., the lowest aptitude humanities teachers are more likely to depart than the highest aptitude humanities teachers. Lastly, the effect of having a larger proportion of students eligible for free lunch is quite different between math/science and humanities teachers across the aptitude distribution. Lower aptitude humanities teachers tend to discount poor students more so than high aptitude humanities teachers. This may be due to organizations such as Teach For America and other alternative certification paths that get high 
aptitude teachers into unfavorable schools.

\subsection{Estimation Results on Subject-specific Scholastic Aptitude for Unfavorable Schools}

Given that teachers sort by school characteristics, we study if the general results on compensation hold for school with high percentages of students eligible for free lunch, the key sorting indicator. To do this, we first re-run the regressions for select teachers in the top quartile of the school lunch variable and test if sorting still occurs. If sorting does not occur, then we can test to see whether higher compensation leads to higher teacher quality among these teachers. One concern is that state fixed effects rely on within-state variation, which subsampling the data may eliminate. Indeed, the intraclass correlation on the subsample data for lifetime compensation is .66 and, on average, 50 percent of all teachers within a state are found in 7 districts. This implies that state fixed effects and the compensation effects cannot be jointly estimated. Given that omitted variable bias is quite minimal in the full sample for math/science/humanities teachers and that excluding state fixed effects downward bias the compensation coefficient, the exclusion is tolerable.

For the teachers in the top quartile of schools with student eligible for free lunch, we find that school characteristics do not affect the quality of teachers hired, indicating that little sorting takes place among this subset of schools (See Table 8). The results also suggest that schools that can increase compensation are able to raise teachers' subject-specific scholastic aptitude. For everyone $1 \%$ increase in lifetime compensation, teacher aptitude increases by 6 percentiles for math/science teachers and 11 percentiles for humanities teachers. Thus, compensation seems to have an even higher rate of return in these schools. Merit/bonus pay as well as additional activities pay do not significantly increase the aptitude of math/science teachers hired and bonus/merit pay has a small impact for humanities teachers. Similar to the baseline results, 
higher aptitude teachers tend to leave teaching at faster rates, and even more so for these schools. The quantile regression results in Table 9 and Figure 2 indicate that teachers respond differently depending on the quality of the teacher hired. Increasing lifetime compensation has no effect on math/science teachers until the $37^{\text {th }}$ percentile and the $55^{\text {th }}$ percentile for humanities teachers. Similar to the full sample, the effect on humanities teachers is much larger than that on math/sciecne teachers.

\section{Conclusion and Policy Implication}

In this study we examine the effects of compensation on two measures of teacher quality: general scholastic aptitude and subject-specific scholastic aptitude. We find strong evidence that salary schedules reduce the subject-specific aptitude of math, science, and humanities teachers and that teachers sort on student characteristics. We further find that teacher sorting is different across teaching subjects with math/science teachers responding more so to school characteristics than humanities teachers. Furthermore, higher aptitude teachers seem to respond to lifetime compensation increases indicating that school can gain higher aptitude teachers through increases in lifetime compensation. Similar to the literature, those that remain in teaching are of lower scholastic aptitude with math/science teachers being more acutely affected and even more so in unfavorable schools.

This paper brings to light serious concerns on how to get high quality teachers into unfavorable schools. Given the quantile regression results, simply increasing pay across the board will not be effective due to almost 40-60 percent of the scholastic aptitude distribution being unresponsive or responding mildly. Using compensation increases solely for teachers with subject-specific higher aptitudes may very well increase teacher quality. A back-of-the- 
envelope calculation indicates that an increase in permanent income of $\$ 19,241$ for math/science teachers and $\$ 9,717$ for humanities teachers to teach in unfavorable schools may equalize teacher quality across schools. It should be noted though that teachers internalize annual merit/bonus pay and additional school activities differently and that these are not effective at raising teacher quality. It may be that teachers view these incomes as non-binding for schools in the long-run and thus temporary. In any event, if education policy dictates that public schools should be at least equitable on school inputs, it may very well require teachers in unfavorable schools to be compensated with higher permanent incomes. 


\section{References}

Aaronson, D., L. Barrow, and W. Sander. 2007. "Teachers and Student Achievement in the Chicago Public High Schools.” Journal of Labor Economics 25:pp. 95-135.

Ballou, D. 1996. "Do Public Schools Hire the Best Applicants?" The Quarterly Journal of Economics 111:97-133.

Bonesrønning, H., T. Falch, and B. Strøm. 2005. "Teacher sorting, teacher quality, and student composition.” European Economic Review 49:457-483.

Canning, A., and L. Tanglao. 2011. “Ohio Mom Kelly Williams-Bolar Jailed for Sending Kids to Better School District.” Retrieved from http://abcnews.go.com, abcnews.

Clotfelter, C., E. Glennie, H. Ladd, and J. Vigdor. 2008. "Would higher salaries keep teachers in high-poverty schools? Evidence from a policy intervention in North Carolina." Journal of Public Economics 92:1352-1370.

Clotfelter, C.T., H.F. Ladd, and J.L. Vigdor. 2007. "How and Why do Teacher Credentials Matter for Student Achievement?” NBER Working Papers No. 12828, National Bureau of Economic Research, Inc, Jan.

Dorans, N.J. 1999. “Correspondences Between ACT and SAT I Scores.” Research Report No. 99-1, College Board.

Ehrenberg, R.G., and D.J. Brewer. 1994. "Do school and teacher characteristics matter? Evidence from High School and Beyond." Economics of Education Review 13:1-17.

Engel, M., and B.A. Jacob. 2011. "New Evidence on Teacher Labor Supply.” Working Paper No. 16802, National Bureau of Economic Research, February. 
Ferguson, R.F. 1996. "How and Why Money Matters: An Analysis of Alabama Schools.” In H. F. Ladd, ed. Holding Schools Accountable: performance-based reform in education. Brookings Institution Press, chap. 8, pp. 465-98.

—. 1991. "Paying For Public Education: New Evidence on How and Why Money Matters." Journal on Legislation 28:465-498.

Gilpin, G. forthcoming. "Reevaulating the Effect of Non-teaching Wages on Teacher Attrition." Economics of Education Review, pp. in press.

Gilpin, G., and M. Kaganovich. 2009. “The Quantity and Quality of Teachers: A Dynamic Trade-off.” CESifo Working Paper Series No. 2516, CESifo Group Munich.

Goldhaber, D., and E. Anthony. 2007. “Can Teacher Quality Be Effectively Assessed? National Board Certification as a Signal of Effective Teaching." The Review of Economics and Statistics 89:134-150.

Greenwald, R., L.V. Hedges, and R.D. Laine. 1996. "The Effect of School Resources on Student Achievement." Review of Educational Research 66:pp. 361-396.

Hanushek, E.A. 2010. “The Economic Value of Higher Teacher Quality.” Working Paper No. 16606, National Bureau of Economic Research, December.

—. 1986. "The Economics of Schooling: Production and Efficiency in Public Schools." Journal of Economic Literature 24:1141-77.

—. 1981. "Throwing money at schools." Journal of Policy Analysis and Management 1:19-41.

Hanushek, E.A., J.F. Kain, D.M. O’Brien, and S.G. Rivkin. 2005. "The Market for Teacher Quality.” Working Paper No. 11154, National Bureau of Economic Research, February. 
Hanushek, E.A., J.F. Kain, and S.G. Rivkin. 1999. “Do Higher Salaries Buy Better Teachers?” NBER Working Papers No. 7082, National Bureau of Economic Research, Inc, Apr.

Heutel, G. 2009. "Testing implications of a tournament model of school district salary schedules." Economics of Education Review 28:143-151.

Imazeki, J. 2005. “Teacher salaries and teacher attrition.” Economics of Education Review 24:431-449.

Jackson, C.K. 2009. "Student Demographics, Teacher Sorting, and Teacher Quality: Evidence from the End of School Desegregation.” Journal of Labor Economics 27:pp. 213-256.

Lankford, H., S. Loeb, and J. Wyckoff. 2002. "Teacher Sorting and the Plight of Urban Schools: A Descriptive Analysis." Educational Evaluation and Policy Analysis 24:37-62.

Levinson, A.M. 1988. "Reexamining teacher preferences and compensating wages.” Economics of Education Review 7:357-364.

Loeb, S., and M.E. Page. 2000. "Examining the Link between Teacher Wages and Student Outcomes: The Importance of Alternative Labor Market Opportunities and Non-Pecuniary Variation." The Review of Economics and Statistics 82:pp. 393-408.

Ma, L., and R. Koenker. 2006. "Quantile regression methods for recursive structural equation models." Journal of Econometrics 134:471-506.

Monk, D.H. 1994. "Subject area preparation of secondary mathematics and science teachers and student achievement." Economics of Education Review 13:125-145.

Podgursky, M. 2008. “"'Teams Versus Bureaucracies: Personnel Policy, Wage-Setting, and Teacher Quality in Traditional Public, Charter, and Private Schools"." In M. Berends, 
M. Springer, and H. Walberg, eds. Charter School Outcomes. Lawrence Erlbaum Associates, pp. 61-84.

Podgursky, M., R. Monroe, and D. Watson. 2004. "The academic quality of public school teachers: an analysis of entry and exit behavior." Economics of Education Review 23:507518.

Rockoff, J.E. 2004. "The Impact of Individual Teachers on Student Achievement: Evidence from Panel Data." The American Economic Review 94:pp. 247-252.

Strauss, R.P., and E.A. Sawyer. 1986. "Some new evidence on teacher and student competencies." Economics of Education Review 5:41-48.

Summers, A.A., and B.L. Wolfe. 1977. "Do Schools Make a Difference?” American Economic Review 67:639-52.

Winkler, D.R. 1975. "Educational Achievement and School Peer Group Composition." The Journal of Human Resources 10:pp. 189-204. 
Table 1: Scholastic Aptitudes of College Students and High School Teachers

\begin{tabular}{lcc}
\hline & Mean & Std. Dev. \\
\hline General Aptitude & & \\
All College Students & 50.000 & 34.134 \\
Humanities Majors & 53.294 & 32.857 \\
Math/Sciences Majors & 64.184 & 27.265 \\
Education Majors & 38.661 & 33.364 \\
All Other Majors & 43.594 & 35.287 \\
All Teachers & 49.280 & 16.251 \\
Humanities Teachers & 50.848 & 16.817 \\
Math/Sciences Teachers & 50.371 & 16.788 \\
Special Education Teachers & 46.860 & 15.453 \\
All Other Teachers & 47.825 & 15.274 \\
Subject-specific Aptitude & & \\
Humanities Majors & 50.000 & 34.134 \\
Math/Sciences Majors & 50.000 & 34.134 \\
All Other Majors & 50.000 & 34.134 \\
Humanities Teachers & 46.401 & 17.782 \\
Math/Sciences Teachers & 42.149 & 18.331 \\
Special Education Teachers & 50.494 & 16.762 \\
All Other Teachers & 49.435 & 17.309 \\
\hline
\end{tabular}

Note: General scholastic aptitude is measured as the percentile in the distribution of all college students. Subject-specific scholastic aptitude is measured as the percentile in the respective subject distribution. 
Table 2: High School Teachers' College Degree by Teaching Subject ${ }^{a}$

\begin{tabular}{|c|c|c|c|c|}
\hline \multirow[t]{2}{*}{ Teaching Subject } & \multicolumn{4}{|c|}{ Majors } \\
\hline & Humanities & Math/Sciences & Education & All Other Majors \\
\hline Humanities & $74.8 \%$ & $2.0 \%$ & $36.5 \%$ & $6.7 \%$ \\
\hline Math/Sciences & $9.1 \%$ & $73.0 \%$ & $31.8 \%$ & $6.0 \%$ \\
\hline All Other Subjects ${ }^{b}$ & $11.5 \%$ & $8.4 \%$ & $55.9 \%$ & $35.7 \%$ \\
\hline Correlation $^{c}$ & $.86^{* *}$ & $.76^{* * *}$ & $.63^{* *}$ & $.85^{* *}$ \\
\hline
\end{tabular}

a: Rows do not sum to $100 \%$ due to double majors and second degrees.

b: Excludes special education teachers.

c: Correlation between general aptitude and subject-specific aptitude. ${ }^{* *} p<0.01$

Table 3: Summary Statistics by \% of Students Eligible for Free Lunch

\begin{tabular}{|c|c|c|c|c|c|c|}
\hline \multicolumn{7}{|c|}{ Humanities Teachers } \\
\hline \multirow[t]{2}{*}{$\%$ Free lunch } & \multicolumn{2}{|c|}{$\begin{array}{c}\text { Subject-specific } \\
\text { Scholastic Aptitude }\end{array}$} & \multirow{2}{*}{$\begin{array}{c}\text { Degree in } \\
\text { Subject }\end{array}$} & \multicolumn{2}{|c|}{$\log$ (Per. Inc.) } & \multirow{2}{*}{$\begin{array}{l}\begin{array}{l}\text { Annual Cost per Unit } \\
\text { of Scholastic Aptitude }\end{array} \\
\text { Mean }^{a}\end{array}$} \\
\hline & Mean & Std. Dev. & & Mean & Std. Dev. & \\
\hline Top Quartile & 42.8 & 17.99 & $80.2 \%$ & 14.48 & 0.18 & 1130.67 \\
\hline Third Quartile & 46.0 & 16.61 & $82.5 \%$ & 14.46 & 0.19 & 1036.47 \\
\hline Second Quartile & 49.1 & 17.03 & $85.4 \%$ & 14.50 & 0.19 & 1008.09 \\
\hline Bottom Quartile & 50.2 & 17.86 & $87.3 \%$ & 14.59 & 0.21 & 1082.91 \\
\hline Diff. $1^{s t}$ and $4^{\text {th }} \mathrm{Q}$ & 7.4 & & $7.1 \%$ & 0.12 & & -47.77 \\
\hline \multicolumn{7}{|c|}{ Math/Science Teachers } \\
\hline$\%$ Free lunch & \multicolumn{2}{|c|}{$\begin{array}{c}\text { Subject-specific } \\
\text { Scholastic Aptitude }\end{array}$} & $\begin{array}{l}\text { Degree in } \\
\text { Subject }\end{array}$ & \multicolumn{2}{|c|}{$\log ($ Per. Inc.) } & $\begin{array}{l}\text { Annual Cost per Unit } \\
\text { of Scholastic Aptitude }\end{array}$ \\
\hline & Mean & Std. Dev. & Mean & Mean & Std. Dev. & $\operatorname{Mean}^{a}$ \\
\hline Top Quartile & 38.77 & 18.51 & $75.9 \%$ & 14.47 & 0.19 & 1240.84 \\
\hline Third Quartile & 42.03 & 17.60 & $77.9 \%$ & 14.47 & 0.18 & 1139.45 \\
\hline Second Quartile & 45.37 & 17.37 & $81.8 \%$ & 14.50 & 0.18 & 1092.78 \\
\hline Bottom Quartile & 46.61 & 18.29 & $84.3 \%$ & 14.59 & 0.21 & 1167.56 \\
\hline Diff. $1^{s t}$ and $4^{\text {th }} \mathrm{Q}$ & 7.84 & & $8.4 \%$ & 0.12 & & -73.28 \\
\hline
\end{tabular}

a: Geometric mean. 


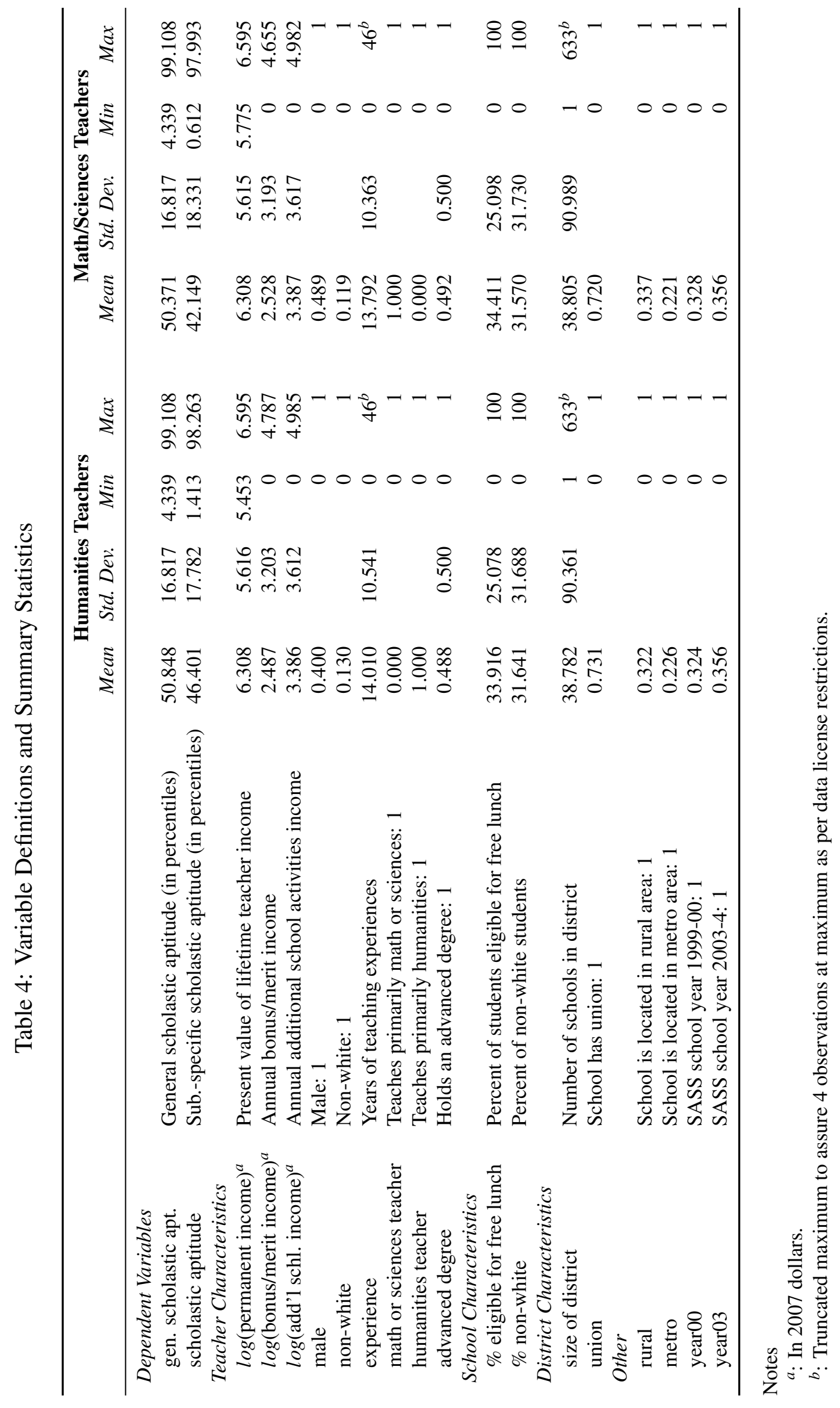


Table 5: Coefficient Estimates on General Scholastic Aptitude Regressions by Teaching Subject

\begin{tabular}{|c|c|c|c|c|c|c|}
\hline \multirow[b]{2}{*}{$\log ($ permanent income $)$} & \multirow{2}{*}{$\begin{array}{c}\text { All Tchrs } \\
7.397 * * * \\
(1.067)\end{array}$} & \multirow{2}{*}{$\begin{array}{c}\text { Non-Math/Sci/Hum } \\
6.261^{* * *} \\
(1.462)\end{array}$} & \multicolumn{2}{|c|}{ Math/Sciences } & \multicolumn{2}{|c|}{ Humanities } \\
\hline & & & $\begin{array}{c}7.251^{* * *} * \\
(1.296)\end{array}$ & $\begin{array}{c}7.519 * * * \\
(1.880)\end{array}$ & $\begin{array}{c}6.976 * * * \\
(1.172)\end{array}$ & $\begin{array}{c}8.132 * * * \\
(1.599)\end{array}$ \\
\hline $\log$ (bonus/merit income) & $\begin{array}{c}0.212 * * * \\
(0.041)\end{array}$ & $\begin{array}{c}0.241^{* * *} * \\
(0.065)\end{array}$ & $\begin{array}{c}0.268 * * * \\
(0.075)\end{array}$ & $\begin{array}{c}0.178 * * \\
(0.077)\end{array}$ & $\begin{array}{c}0.312 * * * \\
(0.070)\end{array}$ & $\begin{array}{c}0.209 * * * \\
(0.070)\end{array}$ \\
\hline $\log ($ addl schl. income $)$ & $\begin{array}{l}-0.016 \\
(0.028)\end{array}$ & $\begin{array}{c}0.049 \\
(0.043)\end{array}$ & $\begin{array}{c}0.015 \\
(0.051)\end{array}$ & $\begin{array}{l}-0.071 \\
(0.050)\end{array}$ & $\begin{array}{c}0.062 \\
(0.048)\end{array}$ & $\begin{array}{c}-0.027 \\
(0.047)\end{array}$ \\
\hline math/sci teacher & $\begin{array}{c}2.083 * * * \\
(0.245)\end{array}$ & & & & & \\
\hline humanities teacher & $\begin{array}{c}2.599 * * * \\
(0.233)\end{array}$ & & & & & \\
\hline special eduction teacher & $\begin{array}{c}-1.733 * * * \\
(0.490)\end{array}$ & $\begin{array}{c}-1.232 * * \\
(0.511)\end{array}$ & & & & \\
\hline advanced degree & $\begin{array}{c}1.758 * * * \\
(0.218)\end{array}$ & $\begin{array}{c}1.175^{* * * *} \\
(0.332)\end{array}$ & $\begin{array}{c}1.458 * * * \\
(0.422)\end{array}$ & $\begin{array}{c}1.836 * * * \\
(0.420)\end{array}$ & $\begin{array}{c}2.057 * * * \\
(0.382)\end{array}$ & $\begin{array}{c}2.253 * * * \\
(0.380)\end{array}$ \\
\hline experience & $\begin{array}{c}-0.103 * * * \\
(0.010)\end{array}$ & $\begin{array}{c}-0.055^{* * *} \\
(0.015)\end{array}$ & $\begin{array}{c}-0.136 * * * \\
(0.020)\end{array}$ & $\begin{array}{c}-0.125 * * * \\
(0.019)\end{array}$ & $\begin{array}{c}-0.136^{* * *} * \\
(0.018)\end{array}$ & $\begin{array}{c}-0.127 * * * \\
(0.018)\end{array}$ \\
\hline$\%$ eligible for free lunch & $\begin{array}{c}-0.041 * * * \\
(0.006)\end{array}$ & $\begin{array}{c}-0.036^{* * *} \\
(0.008)\end{array}$ & $\begin{array}{c}-0.077 * * * \\
(0.012)\end{array}$ & $\begin{array}{c}-0.045^{* * *} * \\
(0.011)\end{array}$ & $\begin{array}{c}-0.078 * * * \\
(0.010)\end{array}$ & $\begin{array}{c}-0.044 * * * \\
(0.010)\end{array}$ \\
\hline$\%$ non-white students & $\begin{array}{c}-0.010 \\
(0.007)\end{array}$ & $\begin{array}{c}-0.022 * * \\
(0.009)\end{array}$ & $\begin{array}{c}-0.016 \\
(0.011)\end{array}$ & $\begin{array}{c}-0.002 \\
(0.011)\end{array}$ & $\begin{array}{c}-0.014 \\
(0.010)\end{array}$ & $\begin{array}{c}-0.000 \\
(0.010)\end{array}$ \\
\hline rural & $\begin{array}{c}-0.717 * * * \\
(0.275)\end{array}$ & $\begin{array}{c}-0.369 \\
(0.391)\end{array}$ & $\begin{array}{c}-0.245 \\
(0.500)\end{array}$ & $\begin{array}{l}-0.687 \\
(0.469)\end{array}$ & $\begin{array}{c}-0.448 \\
(0.468)\end{array}$ & $\begin{array}{c}-1.102 * * \\
(0.441)\end{array}$ \\
\hline metro & $\begin{array}{c}1.007 * * * \\
(0.335)\end{array}$ & $\begin{array}{c}1.365 * * * \\
(0.483)\end{array}$ & $\begin{array}{c}1.978 * * * \\
(0.601)\end{array}$ & $\begin{array}{c}1.288 * * \\
(0.578)\end{array}$ & $\begin{array}{c}1.149 * * \\
(0.532)\end{array}$ & $\begin{array}{c}0.625 \\
(0.490)\end{array}$ \\
\hline union & $\begin{array}{c}-0.757 * * * \\
(0.238)\end{array}$ & $\begin{array}{c}-0.113 \\
(0.364)\end{array}$ & $\begin{array}{c}0.186 \\
(0.431)\end{array}$ & $\begin{array}{c}-0.839 * \\
(0.438)\end{array}$ & $\begin{array}{c}-0.202 \\
(0.406)\end{array}$ & $\begin{array}{c}-1.285 * * * \\
(0.421)\end{array}$ \\
\hline size of district & $\begin{array}{c}0.005 \\
(0.003)\end{array}$ & $\begin{array}{c}0.002 \\
(0.004)\end{array}$ & $\begin{array}{c}0.013 * * * \\
(0.004)\end{array}$ & $\begin{array}{c}0.010 * * \\
(0.005)\end{array}$ & $\begin{array}{c}0.011 * * * \\
(0.004)\end{array}$ & $\begin{array}{c}0.003 \\
(0.004)\end{array}$ \\
\hline Observations $^{a}$ & 25010 & 9030 & 7110 & 7110 & 8870 & 8870 \\
\hline State Fixed Effects & Yes & Yes & No & Yes & No & Yes \\
\hline Adjusted $R^{2}$ & 0.141 & 0.159 & 0.083 & 0.141 & 0.066 & 0.123 \\
\hline
\end{tabular}

Cluster robust standard errors in parentheses.

$* p<.1,{ }^{* *} p<.05, * * * p<.01$

$a^{a}$ : Rounded to the nearest 10 as per data license restrictions.

Regressions include all other variables listed in Table 4. 
Table 6: Coefficient Estimates on Subject-specific Scholastic Aptitude Regressions by Teaching Subject

\begin{tabular}{|c|c|c|c|c|c|c|}
\hline \multirow[b]{2}{*}{$\log ($ permanent income $)$} & \multirow{2}{*}{$\begin{array}{c}\text { All } \\
5.685^{* * * *} \\
(1.112)\end{array}$} & \multirow{2}{*}{$\begin{array}{c}\text { non-Math/Sci/Hum } \\
3.239 * * \\
(1.643)\end{array}$} & \multicolumn{2}{|c|}{ Math/Sciences } & \multicolumn{2}{|c|}{ Humanities } \\
\hline & & & $\begin{array}{c}6.650 * * * \\
(1.405)\end{array}$ & $\begin{array}{l}5.068 * * \\
(2.030)\end{array}$ & $\begin{array}{c}7.635 * * * \\
(1.195)\end{array}$ & $\begin{array}{c}7.913 * * * \\
(1.615)\end{array}$ \\
\hline $\log ($ bonus/merit income $)$ & $\begin{array}{c}0.204 * * * \\
(0.045)\end{array}$ & $\begin{array}{c}0.255^{* * *} * \\
(0.072)\end{array}$ & $\begin{array}{c}0.158 * * \\
(0.080)\end{array}$ & $\begin{array}{c}0.171 * * \\
(0.082)\end{array}$ & $\begin{array}{c}0.261 * * * \\
(0.076)\end{array}$ & $\begin{array}{c}0.174 * * \\
(0.074)\end{array}$ \\
\hline $\log$ (addl schl. income) & $\begin{array}{c}-0.081 * * * \\
(0.030)\end{array}$ & $\begin{array}{c}-0.037 \\
(0.047)\end{array}$ & $\begin{array}{c}-0.048 \\
(0.055)\end{array}$ & $\begin{array}{c}-0.134 * * \\
(0.054)\end{array}$ & $\begin{array}{c}0.023 \\
(0.050)\end{array}$ & $\begin{array}{c}-0.065 \\
(0.049)\end{array}$ \\
\hline math/sci teacher & $\begin{array}{c}-8.232 * * * \\
(0.280)\end{array}$ & & & & & \\
\hline humanities teacher & $\begin{array}{c}-4.466 * * * \\
(0.258)\end{array}$ & & & & & \\
\hline special eduction teacher & $\begin{array}{c}-2.471 * * * \\
(0.536)\end{array}$ & $\begin{array}{c}-1.715^{* * * *} \\
(0.551)\end{array}$ & & & & \\
\hline advanced degree & $\begin{array}{c}1.902 * * * \\
(0.242)\end{array}$ & $\begin{array}{c}1.500 * * * \\
(0.381)\end{array}$ & $\begin{array}{c}1.962 * * * \\
(0.462)\end{array}$ & $\begin{array}{c}2.134 * * * \\
(0.460)\end{array}$ & $\begin{array}{c}1.970 * * * \\
(0.408)\end{array}$ & $\begin{array}{c}2.152 * * * \\
(0.405)\end{array}$ \\
\hline experience & $\begin{array}{c}-0.121 * * * \\
(0.011)\end{array}$ & $\begin{array}{c}-0.098 * * * \\
(0.017)\end{array}$ & $\begin{array}{c}-0.161 * * * \\
(0.022)\end{array}$ & $\begin{array}{c}-0.146^{* * *} \\
(0.021)\end{array}$ & $\begin{array}{c}-0.123 * * * \\
(0.020)\end{array}$ & $\begin{array}{c}-0.112 * * * \\
(0.019)\end{array}$ \\
\hline$\%$ eligible for free lunch & $\begin{array}{c}-0.041 * * * \\
(0.007)\end{array}$ & $\begin{array}{c}-0.040^{* * *} * \\
(0.009)\end{array}$ & $\begin{array}{c}-0.077 * * * \\
(0.012)\end{array}$ & $\begin{array}{c}-0.046^{* * *} * \\
(0.012)\end{array}$ & $\begin{array}{c}-0.074 * * * \\
(0.011)\end{array}$ & $\begin{array}{c}-0.041 * * * \\
(0.010)\end{array}$ \\
\hline$\%$ non-white students & $\begin{array}{c}-0.016^{* *} \\
(0.007)\end{array}$ & $\begin{array}{c}-0.026 * * \\
(0.010)\end{array}$ & $\begin{array}{c}-0.033 * * * \\
(0.012)\end{array}$ & $\begin{array}{c}-0.013 \\
(0.013)\end{array}$ & $\begin{array}{c}-0.029 * * * \\
(0.010)\end{array}$ & $\begin{array}{c}-0.004 \\
(0.010)\end{array}$ \\
\hline rural & $\begin{array}{c}-0.611 * * \\
(0.300)\end{array}$ & $\begin{array}{l}0.0479 \\
(0.442)\end{array}$ & $\begin{array}{c}-0.562 \\
(0.548)\end{array}$ & $\begin{array}{c}-1.298 * * \\
(0.527)\end{array}$ & $\begin{array}{c}0.065 \\
(0.504)\end{array}$ & $\begin{array}{c}-0.787 * \\
(0.476)\end{array}$ \\
\hline metro & $\begin{array}{c}0.822 * * \\
(0.351)\end{array}$ & $\begin{array}{l}1.010 * \\
(0.516)\end{array}$ & $\begin{array}{c}1.982 * * * \\
(0.635)\end{array}$ & $\begin{array}{l}1.324 * * \\
(0.604)\end{array}$ & $\begin{array}{l}1.232 * * \\
(0.580)\end{array}$ & $\begin{array}{c}0.402 \\
(0.536)\end{array}$ \\
\hline union & $\begin{array}{c}-0.355 \\
(0.263)\end{array}$ & $\begin{array}{c}0.295 \\
(0.409)\end{array}$ & $\begin{array}{l}0.933 * \\
(0.477)\end{array}$ & $\begin{array}{l}-0.428 \\
(0.490)\end{array}$ & $\begin{array}{c}0.431 \\
(0.429)\end{array}$ & $\begin{array}{c}-0.859 * \\
(0.448)\end{array}$ \\
\hline size of district & $\begin{array}{c}0.005 \\
(0.003)\end{array}$ & $\begin{array}{c}0.002 \\
(0.005)\end{array}$ & $\begin{array}{c}0.011 * * * \\
(0.004)\end{array}$ & $\begin{array}{l}0.008 * \\
(0.004)\end{array}$ & $\begin{array}{c}0.011 * * * \\
(0.003)\end{array}$ & $\begin{array}{c}0.003 \\
(0.003)\end{array}$ \\
\hline Observations $^{a}$ & 24700 & 8920 & 6990 & 6990 & 8790 & 8790 \\
\hline State Fixed Effects & Yes & Yes & No & Yes & No & Yes \\
\hline Adjusted $R^{2}$ & 0.144 & 0.143 & 0.074 & 0.126 & 0.060 & 0.116 \\
\hline
\end{tabular}

Cluster robust standard errors in parentheses.

$* p<.1, * * p<.05, * * * p<.01$

$a:$ Rounded to the nearest 10 as per data license restrictions.

Regressions include all other variables listed in Table 4. 
Table 7: Coefficient Estimates on Subject-Specific Scholastic Aptitude Quantile Regressions

\begin{tabular}{|c|c|c|c|c|c|c|}
\hline \multirow[b]{2}{*}{ Quantile } & \multicolumn{3}{|c|}{ Math/Science Teachers } & \multicolumn{3}{|c|}{ Humanities Teachers } \\
\hline & 25 & 50 & 75 & 25 & 50 & 75 \\
\hline \multicolumn{7}{|c|}{ Compensation Characteristics } \\
\hline $\log ($ permanent income $)$ & $\begin{array}{c}2.637 \\
(1.879)\end{array}$ & $\begin{array}{c}6.769 * * * \\
(2.570)\end{array}$ & $\begin{array}{c}5.831 * * \\
(2.875)\end{array}$ & $\begin{array}{c}4.891 * * * \\
(1.853)\end{array}$ & $\begin{array}{c}8.353 * * * \\
(1.597)\end{array}$ & $\begin{array}{c}9.340 * * * \\
(1.943)\end{array}$ \\
\hline $\log$ (bonus/merit income) & $\begin{array}{c}0.097 \\
(0.085)\end{array}$ & $\begin{array}{l}0.171^{*} \\
(0.103)\end{array}$ & $\begin{array}{c}0.120 \\
(0.105)\end{array}$ & $\begin{array}{c}0.155^{* *} \\
(0.070)\end{array}$ & $\begin{array}{c}0.091 \\
(0.072)\end{array}$ & $\begin{array}{c}0.152 \\
(0.116)\end{array}$ \\
\hline $\log ($ addl schl. income $)$ & $\begin{array}{c}-0.132 * * \\
(0.054)\end{array}$ & $\begin{array}{c}-0.143 * * \\
(0.072)\end{array}$ & $\begin{array}{c}-0.173^{* *} \\
(0.080)\end{array}$ & $\begin{array}{c}0.001 \\
(0.047)\end{array}$ & $\begin{array}{l}-0.027 \\
(0.046)\end{array}$ & $\begin{array}{l}-0.037 \\
(0.066)\end{array}$ \\
\hline advanced degree & $\begin{array}{c}1.320 * * * \\
(0.489)\end{array}$ & $\begin{array}{c}1.864 * * * \\
(0.617)\end{array}$ & $\begin{array}{c}2.337 * * * \\
(0.614)\end{array}$ & $\begin{array}{c}1.120^{* * * *} \\
(0.427)\end{array}$ & $\begin{array}{c}1.795 * * * \\
(0.418)\end{array}$ & $\begin{array}{c}2.038 * * * \\
(0.623)\end{array}$ \\
\hline experience & $\begin{array}{c}-0.089 * * * \\
(0.022)\end{array}$ & $\begin{array}{c}-0.099 * * * \\
(0.025)\end{array}$ & $\begin{array}{c}-0.152 * * * \\
(0.028)\end{array}$ & $\begin{array}{c}-0.105^{* * *} * \\
(0.020)\end{array}$ & $\begin{array}{c}-0.084^{* * * *} \\
(0.017)\end{array}$ & $\begin{array}{c}-0.073 * * * \\
(0.025)\end{array}$ \\
\hline$\%$ eligible for free lunch & $\begin{array}{c}-0.033 * * * \\
(0.012)\end{array}$ & $\begin{array}{c}-0.048 * * * \\
(0.014)\end{array}$ & $\begin{array}{c}-0.048 * * * \\
(0.018)\end{array}$ & $\begin{array}{c}-0.050 * * * \\
(0.011)\end{array}$ & $\begin{array}{c}-0.035^{* * * *} \\
(0.009)\end{array}$ & $\begin{array}{c}-0.022 \\
(0.015)\end{array}$ \\
\hline$\%$ non-white students & $\begin{array}{l}-0.027 * \\
(0.014)\end{array}$ & $\begin{array}{l}-0.013 \\
(0.014)\end{array}$ & $\begin{array}{l}-0.003 \\
(0.018)\end{array}$ & $\begin{array}{c}-0.032 * * * \\
(0.011)\end{array}$ & $\begin{array}{c}-0.012 \\
(0.011)\end{array}$ & $\begin{array}{c}0.010 \\
(0.015)\end{array}$ \\
\hline rural & $\begin{array}{c}-1.145^{* *} \\
(0.557)\end{array}$ & $\begin{array}{l}-0.886 \\
(0.625)\end{array}$ & $\begin{array}{l}-1.258^{*} \\
(0.726)\end{array}$ & $\begin{array}{l}-0.836^{*} \\
(0.459)\end{array}$ & $\begin{array}{l}-0.165 \\
(0.394)\end{array}$ & $\begin{array}{c}-1.417 * * \\
(0.654)\end{array}$ \\
\hline metro & $\begin{array}{c}0.271 \\
(0.639)\end{array}$ & $\begin{array}{c}0.555 \\
(0.815)\end{array}$ & $\begin{array}{c}0.450 \\
(0.828)\end{array}$ & $\begin{array}{l}1.067 * * \\
(0.515)\end{array}$ & $\begin{array}{l}1.087 * * \\
(0.548)\end{array}$ & $\begin{array}{c}-0.838 \\
(0.634)\end{array}$ \\
\hline union & $\begin{array}{c}0.771 \\
(0.498)\end{array}$ & $\begin{array}{l}-0.661 \\
(0.588)\end{array}$ & $\begin{array}{l}-1.119^{*} \\
(0.671)\end{array}$ & $\begin{array}{l}-0.523 \\
(0.425)\end{array}$ & $\begin{array}{l}-0.473 \\
(0.396)\end{array}$ & $\begin{array}{l}-1.094 * \\
(0.641)\end{array}$ \\
\hline size of district & $\begin{array}{c}0.003 \\
(0.005)\end{array}$ & $\begin{array}{l}0.010^{*} \\
(0.005)\end{array}$ & $\begin{array}{c}0.019 * * * \\
(0.006)\end{array}$ & $\begin{array}{l}-0.001 \\
(0.006)\end{array}$ & $\begin{array}{c}0.006 \\
(0.004)\end{array}$ & $\begin{array}{c}0.005 \\
(0.006)\end{array}$ \\
\hline $\begin{array}{l}\text { State Fixed Effects } \\
\text { Observations } \\
\text { Adjusted } R^{2}\end{array}$ & $\begin{array}{l}\text { Yes } \\
6990\end{array}$ & $\begin{array}{l}\text { Yes } \\
6990\end{array}$ & $\begin{array}{l}\text { Yes } \\
6990\end{array}$ & $\begin{array}{c}\text { Yes } \\
8790\end{array}$ & $\begin{array}{l}\text { Yes } \\
8790\end{array}$ & $\begin{array}{c}\text { Yes } \\
8790\end{array}$ \\
\hline
\end{tabular}


Table 8: Coefficient Estimates on Subject-specific Scholastic Aptitude Regressions - Teachers in $4^{\text {th }}$ Quartile of Percent Eligible for Free Lunch Schools

\begin{tabular}{lccc}
\hline & Math/Sci/Hum Teachers & Math/Sciences Teachers & Humanities Teachers \\
\hline $\log$ (permanent income) & $4.258^{* *}$ & $6.093^{*}$ & $10.95^{* * *}$ \\
& $(1.867)$ & $(3.377)$ & $(2.643)$ \\
$\log ($ bonus/merit income) & $0.187^{* *}$ & -0.177 & $0.281^{*}$ \\
& $(0.089)$ & $(0.157)$ & $(0.152)$ \\
$\log$ (addl schl. income) & 0.021 & 0.089 & -0.000 \\
& $(0.063)$ & $(0.107)$ & $(0.102)$ \\
math/sci teacher & $-6.735^{* * *}$ & & \\
advanced degree & $(0.481)$ & & \\
& $0.932^{*}$ & $1.890^{* *}$ & 0.846 \\
experience & $(0.501)$ & $(0.929)$ & $(0.872)$ \\
& $-0.137^{* * *}$ & $-0.174^{* * *}$ & $-0.160^{* * *}$ \\
\% eligible for free lunch & $(0.024)$ & $(0.042)$ & $(0.039)$ \\
& -0.026 & -0.013 & -0.016 \\
$\%$ non-white students & $(0.019)$ & $(0.031)$ & $(0.028)$ \\
& $-0.021^{*}$ & -0.011 & -0.013 \\
rural & $(0.011)$ & $(0.017)$ & $(0.016)$ \\
& -0.960 & $-2.626^{* *}$ & -0.035 \\
metro & $(0.680)$ & $(1.069)$ & $(1.011)$ \\
& 0.807 & 1.651 & 0.097 \\
union & $(0.840)$ & $(1.358)$ & $(1.188)$ \\
& 0.547 & 1.235 & -0.717 \\
size of district & $(0.487)$ & $(0.899)$ & $(0.770)$ \\
& $0.015^{* * *}$ & $0.016^{* *}$ & $0.016^{* * *}$ \\
State Fixed Effects & $(0.003)$ & $(0.008)$ & $(0.004)$ \\
Observations ${ }^{a}$ & No & No & No \\
Adjusted $R^{2}$ & 6250 & 1750 & 0.085 \\
\hline Cly & 0.113 & 0.112 & \\
\hline
\end{tabular}

Cluster robust standard errors in parentheses.

$* p<.1, * * p<.05, * * * p<.01$

$a$ : Rounded to the nearest 10 as per data license restrictions.

Regressions include all other variables listed in Table 4. 
Table 9: Coefficient Estimates on Subject-Specific Scholastic Aptitude Quantile Regressions Teachers in $4^{\text {th }}$ Quartile of Percent Eligible for Free Lunch Schools

\begin{tabular}{|c|c|c|c|c|c|c|}
\hline \multirow[b]{2}{*}{ Quantile } & \multicolumn{3}{|c|}{ Math/Sciences Teachers } & \multicolumn{3}{|c|}{ Humanities Teachers } \\
\hline & 25 & 50 & 75 & 25 & 50 & 75 \\
\hline $\log ($ permanent income $)$ & $\begin{array}{c}0.577 \\
(4.395)\end{array}$ & $\begin{array}{c}9.422 * * * \\
(3.412)\end{array}$ & $\begin{array}{c}12.40 * * * \\
(4.527)\end{array}$ & $\begin{array}{l}1.930 \\
(2.599)\end{array}$ & $\begin{array}{l}6.556^{*} \\
(3.479)\end{array}$ & $\begin{array}{c}17.75 * * * \\
(3.721)\end{array}$ \\
\hline $\log$ (bonus/merit income) & $\begin{array}{l}-0.095 \\
(0.169)\end{array}$ & $\begin{array}{l}-0.108 \\
(0.191)\end{array}$ & $\begin{array}{l}-0.301 \\
(0.235)\end{array}$ & $\begin{array}{c}0.262 \\
(0.186)\end{array}$ & $\begin{array}{c}0.207 \\
(0.172)\end{array}$ & $\begin{array}{c}0.248 \\
(0.235)\end{array}$ \\
\hline $\log ($ addl schl. income $)$ & $\begin{array}{l}-0.049 \\
(0.126)\end{array}$ & $\begin{array}{c}0.074 \\
(0.133)\end{array}$ & $\begin{array}{c}0.136 \\
(0.169)\end{array}$ & $\begin{array}{c}0.002 \\
(0.104)\end{array}$ & $\begin{array}{c}0.130 \\
(0.138)\end{array}$ & $\begin{array}{l}-0.043 \\
(0.149)\end{array}$ \\
\hline advanced degree & $\begin{array}{l}-0.059 \\
(1.084)\end{array}$ & $\begin{array}{c}3.220 * * * \\
(1.073)\end{array}$ & $\begin{array}{l}2.612^{*} \\
(1.496)\end{array}$ & $\begin{array}{c}0.101 \\
(0.920)\end{array}$ & $\begin{array}{c}1.513 \\
(1.067)\end{array}$ & $\begin{array}{c}0.825 \\
(1.247)\end{array}$ \\
\hline experience & $\begin{array}{l}-0.088^{*} \\
(0.046)\end{array}$ & $\begin{array}{c}-0.192 * * * \\
(0.048)\end{array}$ & $\begin{array}{c}-0.251 * * * \\
(0.066)\end{array}$ & $\begin{array}{c}-0.145 * * * \\
(0.040)\end{array}$ & $\begin{array}{c}-0.143 * * * \\
(0.044)\end{array}$ & $\begin{array}{c}-0.153 * * * \\
(0.052)\end{array}$ \\
\hline$\%$ eligible for free lunch & $\begin{array}{l}-0.0164 \\
(0.034)\end{array}$ & $\begin{array}{l}-0.001 \\
(0.039)\end{array}$ & $\begin{array}{l}-0.038 \\
(0.044)\end{array}$ & $\begin{array}{c}-0.056^{* *} \\
(0.027)\end{array}$ & $\begin{array}{l}-0.046 \\
(0.033)\end{array}$ & $\begin{array}{c}0.019 \\
(0.039)\end{array}$ \\
\hline$\%$ non-white students & $\begin{array}{l}-0.0236 \\
(0.020)\end{array}$ & $\begin{array}{l}-0.006 \\
(0.018)\end{array}$ & $\begin{array}{c}0.010 \\
(0.028)\end{array}$ & $\begin{array}{l}-0.012 \\
(0.019)\end{array}$ & $\begin{array}{c}0.001 \\
(0.016)\end{array}$ & $\begin{array}{l}-0.007 \\
(0.021)\end{array}$ \\
\hline rural & $\begin{array}{l}-1.314 \\
(1.042)\end{array}$ & $\begin{array}{c}-2.982 * * \\
(1.198)\end{array}$ & $\begin{array}{l}-2.859 \\
(1.799)\end{array}$ & $\begin{array}{l}-1.096 \\
(1.058)\end{array}$ & $\begin{array}{c}0.959 \\
(1.181)\end{array}$ & $\begin{array}{c}1.313 \\
(1.610)\end{array}$ \\
\hline metro & $\begin{array}{c}1.619 \\
(1.454)\end{array}$ & $\begin{array}{c}0.537 \\
(1.646)\end{array}$ & $\begin{array}{c}1.193 \\
(1.885)\end{array}$ & $\begin{array}{l}-1.499 \\
(1.245)\end{array}$ & $\begin{array}{c}0.363 \\
(1.608)\end{array}$ & $\begin{array}{c}1.020 \\
(1.561)\end{array}$ \\
\hline union & $\begin{array}{l}1.715^{*} \\
(0.900)\end{array}$ & $\begin{array}{l}1.874^{*} \\
(1.046)\end{array}$ & $\begin{array}{c}0.168 \\
(1.274)\end{array}$ & $\begin{array}{l}-0.751 \\
(0.983)\end{array}$ & $\begin{array}{l}-1.196 \\
(0.992)\end{array}$ & $\begin{array}{l}-0.641 \\
(1.419)\end{array}$ \\
\hline size of district & $\begin{array}{l}0.010^{*} \\
(0.006)\end{array}$ & $\begin{array}{c}0.018 * * \\
(0.007)\end{array}$ & $\begin{array}{c}0.034 * * * \\
(0.008)\end{array}$ & $\begin{array}{c}0.023 * * * \\
(0.005)\end{array}$ & $\begin{array}{c}0.022 * * * \\
(0.006)\end{array}$ & $\begin{array}{c}0.021 * * * \\
(0.006)\end{array}$ \\
\hline $\begin{array}{l}\text { State Fixed Effects } \\
\text { Observations }{ }^{a}\end{array}$ & $\begin{array}{c}\text { No } \\
1750\end{array}$ & $\begin{array}{l}\text { No } \\
1750\end{array}$ & $\begin{array}{l}\text { No } \\
1750\end{array}$ & $\begin{array}{c}\text { No } \\
2180\end{array}$ & $\begin{array}{c}\text { No } \\
2180\end{array}$ & $\begin{array}{c}\text { No } \\
2180\end{array}$ \\
\hline
\end{tabular}

Bootstrapped standard errors in parentheses.

$* p<0.05, * * p<0.01$

$a$ : Rounded to the nearest 10 as per data license restrictions.

Regressions include all variables list in Table 4. 
Figure 1: Subject-Specific Scholastic Aptitude Quantile Coefficients
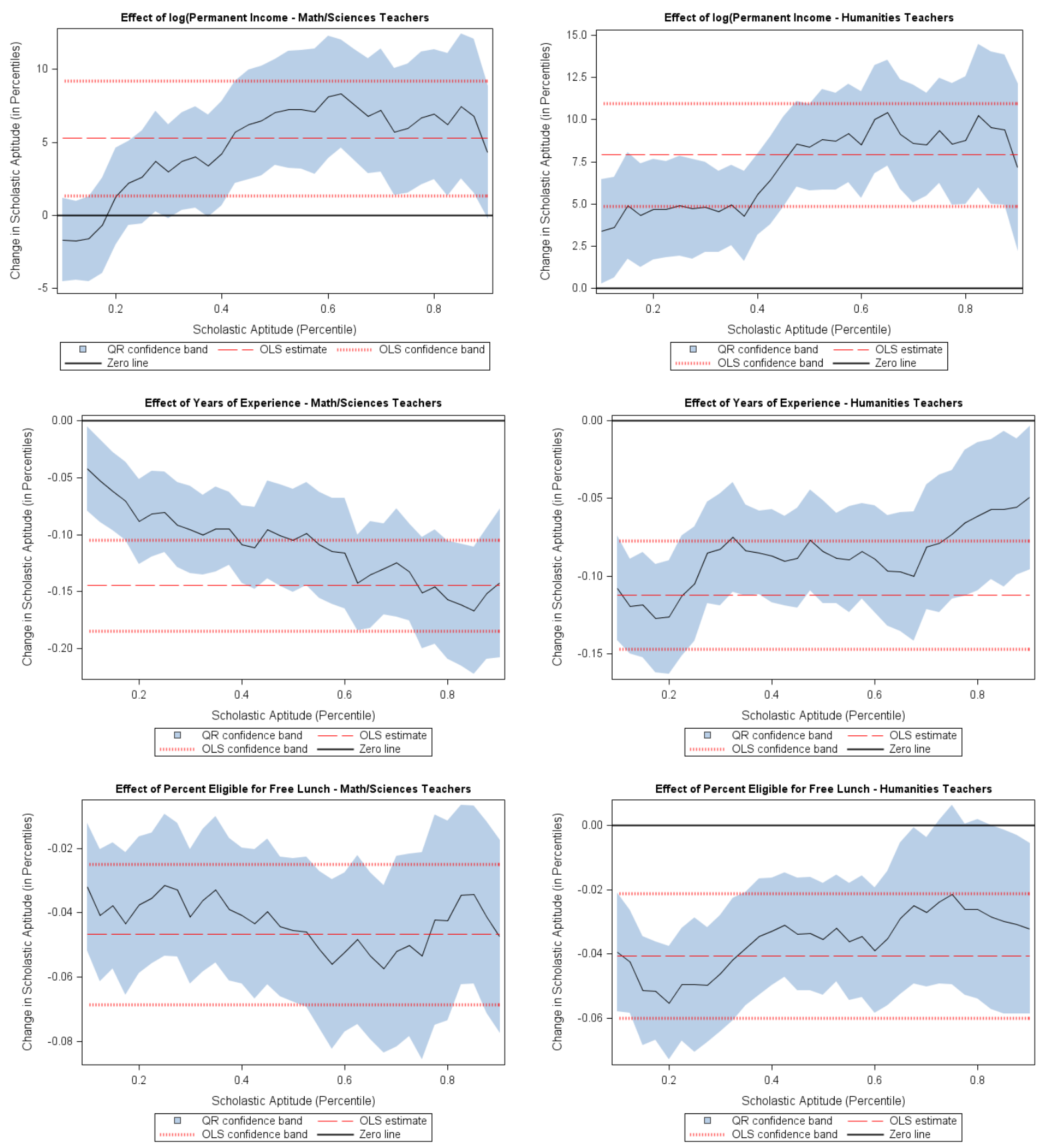
Figure 2: Subject-Specific Scholastic Aptitude Quantile Coefficients - $4^{\text {th }}$ Quartile in $\%$ Elg. for Free Lunch
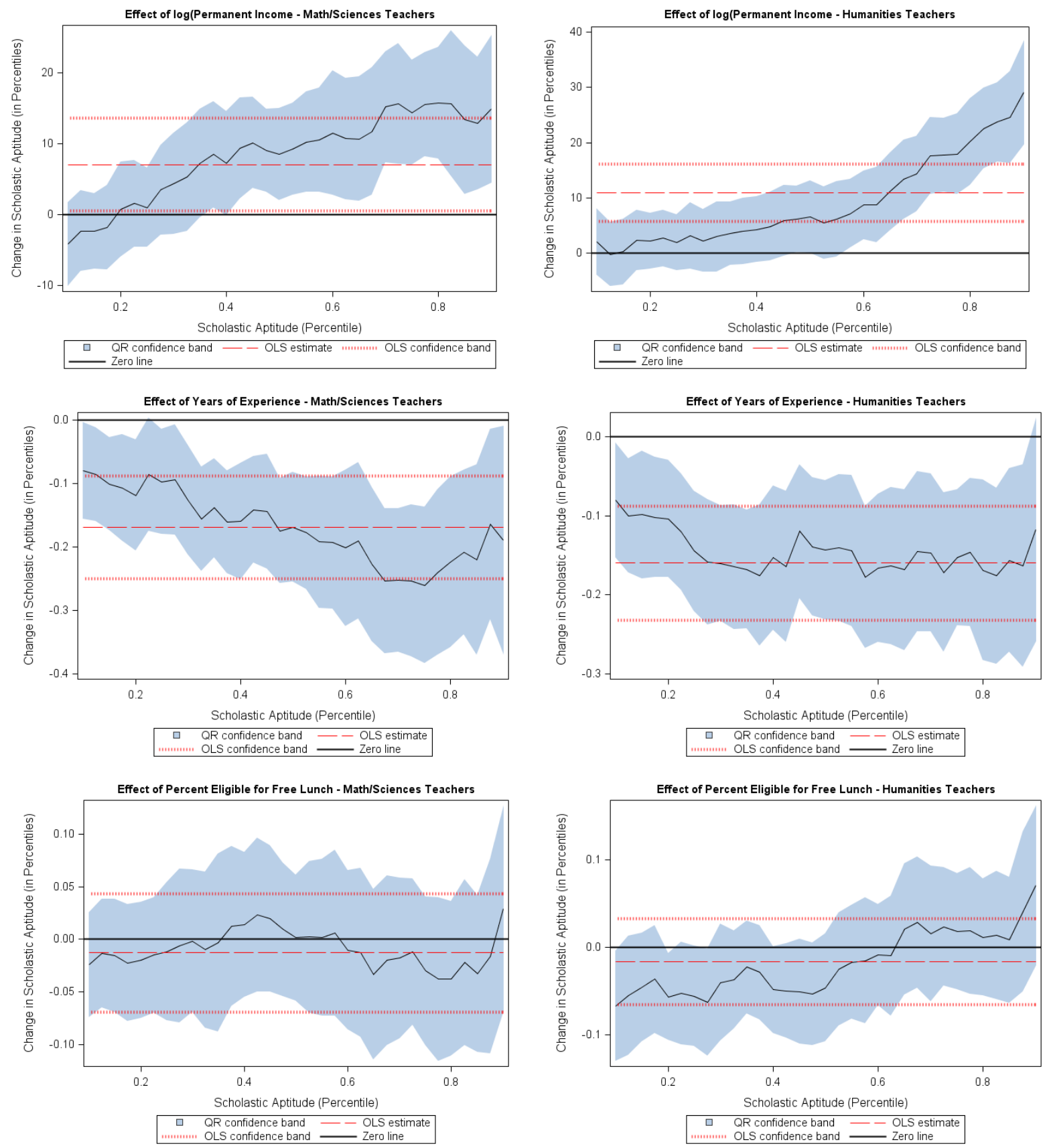
Table A1: College Majors by Subject

\begin{tabular}{lll}
\hline \multicolumn{1}{c}{ Humanities } & & Education \\
\hline Communications or journalism & Agricultural & Autism \\
Economics & Art & Counseling and guidance \\
English literature or composition & Bilingual & Curriculum and instruction \\
French & Business & Deaf and hard-of-hearing \\
German & Cross-cultural & Developmentally delayed \\
History & Early childhood & Early childhood special \\
Humanities & Elementary & al administration \\
Latin & English/language arts & al psychology \\
Law & ESL & Industrial arts \\
Library and information science & Foreign languages & Learning disabilities \\
Multi or interdisciplinary studies & Health & Mentally retarded \\
Native American studies & Home econ & Mildly or moderately disabled \\
Other area or ethnic studies & Kindergarten & Orthopedically impaired \\
Other languages & Mathematics & Other \\
Other social sciences & Music & Other special \\
Philosophy & Native American & Severely disabled \\
Political science and government & Physical & Social studies \\
Psychology & Prekindergarten & Special \\
Public administration or service & Reading & Speech or language impaired \\
Religion or theology & Religious & Trades and industry \\
Russian & Science & Traumatically brain injured \\
Sociology & Secondary & Visually impaired \\
Spanish & Emotionally disturbed behavior disorders \\
\hline \multicolumn{1}{c}{ Math/Sciences } & & All Other Majors \\
\hline Ag and Natl resources & Art, fine and applied & All Other Areas \\
Biology/Life science & Drama or theater & Architecture \\
Chemistry & Music & Business and mgmt \\
Computer science & Visual/performing arts & Environmental design \\
Engineering & & Family consumer science \\
Geology/Earth science & & General studies \\
Mathematics & & Health professions \\
Other natural sciences & & Military science \\
Physics & & \\
Statistics & & \\
\hline & & \\
\hline
\end{tabular}




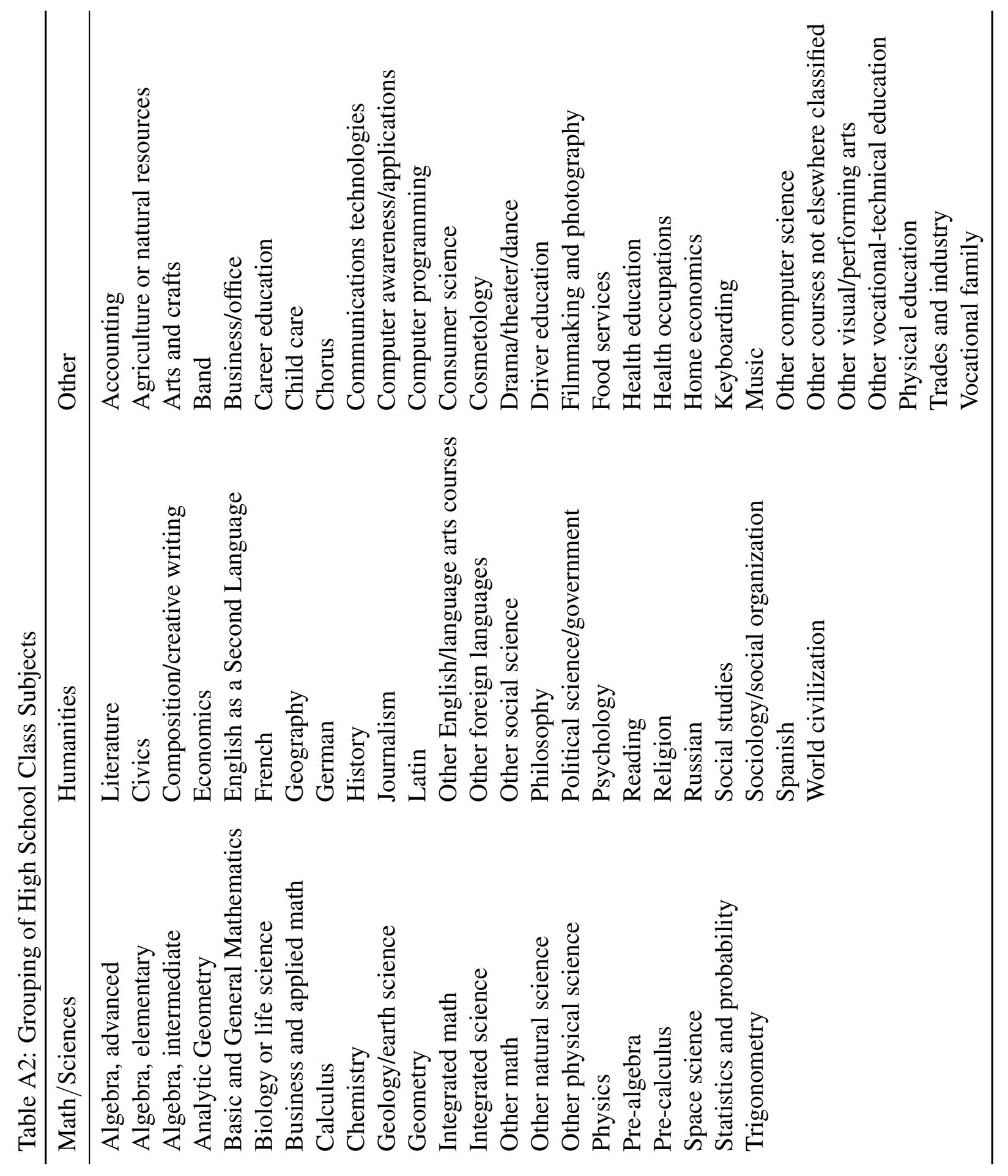


Table A3: College ACT Statistics ${ }^{a}$

\begin{tabular}{rrrr}
\hline Year & Mean & Std. Dev. & Obs $^{b}$ \\
\hline 1990 & 20.155 & 4.995 & 6320 \\
1993 & 21.244 & 4.752 & 23590 \\
1996 & 21.422 & 4.728 & 17690 \\
2000 & 21.975 & 4.703 & 49930 \\
2004 & 22.416 & 4.762 & 24040 \\
2008 & 22.727 & 4.652 & 41580
\end{tabular}

$a$ : SAT scores are converted to ACT scores. See Dorans (1999) for conversion details.

${ }^{b}$ : Rounded to the nearest 10 as per data license restrictions.

Source: National Postsecondary Student Aid Study (NPSAS) - Restricted versions 